\title{
Emissions and Possible Environmental Implication of Engineered Nanomaterials (ENMs) in the Atmosphere
}

\author{
Astrid C. John ${ }^{1, *}$, Miriam Küpper ${ }^{1}$, Astrid M.M. Manders-Groot ${ }^{2}$, Bruno Debray ${ }^{3}$, \\ Jean-Marc Lacome ${ }^{3}$ and Thomas A.J. Kuhlbusch ${ }^{4,5}$ \\ 1 Institute for Energy and Environmental Technology (IUTA), Bliersheimer Str. 58-60, 47229 Duisburg, \\ Germany; kuepper@iuta.de \\ 2 Netherlands Organisation for Applied Scientific Research TNO, PO Box 80015, 3508 TA Utrecht, \\ The Netherlands; astrid.manders@tno.nl \\ 3 Institut National de l'Environnement Industriel et des Risques (INERIS), Parc ALATA, \\ 60550 Verneuil-en-Halatte, France; Bruno.DEBRAY@ineris.fr (B.D.); Jean-Marc.LACOME@ineris.fr (J.-M.L.) \\ 4 Federal Institute for Occupational Safety and Health (BAuA), Friedrich-Henkel-Weg 1-25, 44149 Dortmund, \\ Germany; Kuhlbusch.Thomas@baua.bund.de \\ 5 CENIDE, University Duisburg-Essen, Carl-Benz-Str. 199, 47057 Duisburg, Germany \\ * Correspondence: john@iuta.de; Tel.: +49-2065-418-214
}

Academic Editor: Robert W. Talbot

Received: 5 March 2017; Accepted: 29 April 2017; Published: 5 May 2017

\begin{abstract}
In spite of the still increasing number of engineered nanomaterial (ENM) applications, large knowledge gaps exist with respect to their environmental fate, especially after release into air. This review aims to summarize the current knowledge of emissions and behavior of airborne engineered nanomaterials. The whole ENM lifecycle is considered from the perspective of possible releases into the atmosphere. Although in general, emissions during use phase and end-of-life seem to play a minor role compared to entry into soil and water, accidental and continuous emissions into air can occur especially during production and some use cases such as spray application. Implications of ENMs on the atmosphere as e.g., photo-catalytic properties or the production of reactive oxygen species are reviewed as well as the influence of physical processes and chemical reactions on the ENMs. Experimental studies and different modeling approaches regarding atmospheric transformation and removal are summarized. Some information exists especially for ENMs, but many issues can only be addressed by using data from ultrafine particles as a substitute and research on the specific implications of ENMs in the atmosphere is still needed.
\end{abstract}

Keywords: engineered nanomaterials; ENMs; release; transformation processes; aerosols; ultrafine particles; atmospheric transport

\section{Introduction}

Engineered nanomaterials (ENMs) are one of the subgroups of "nanomaterials" comprising also natural and unintentionally produced nanomaterials [1]. They are commonly defined as materials containing particles or having structures with at least one dimension within 1-100 nm, or powders with $50 \%$ or more of the particles by number having one or more external dimensions in the size range 1-100 $\mathrm{nm}$ [1]. Other definitions, e.g., based on a threshold in volume-specific surface area [2,3] or concentrating on properties differing from those of bulk samples rather than on a generalized size range [4], have also been proposed. These unique properties are inter alia caused by the large percentage of atoms at the surface and an increasing number of crystalline defects with decreasing particle size [4]. This may lead to increased reactivity, high conductivity and exceptional optical properties [5-7] making them valuable for numerous applications. 
Developments of new materials and technologies, here ENMs, also require the investigation of possible implications for humans and the environment [8-10]. These investigations become more important with the increased use of ENMs [11-13]. Conservative global market estimates for e.g., metal oxide nanomaterials added up to 270,000 tons in 2012, rising to 1,663,000 tons by 2020 [14]. As a consequence, an exposure risk to ENMs may become a concern for the population $[15,16]$.

Health effects of anthropogenic and naturally emitted UFP (ultrafine particles $<100 \mathrm{~nm}$ ) as well as ENMs are still under investigation, with regulatory concerns in air quality control [11]. However, since physicochemical characteristics of intentionally manufactured ENMs might differ from those of unintentionally produced UFP in numerous ways, such as aspect ratio, reactivity, chemical composition and toxicity $[17,18]$, further progress has to be made assessing alternative metrics, such as airborne particle number or particle surface area concentration, and their link to health and environmental effects of the multiplicity of ENMs $[19,20]$. Furthermore, it is necessary not just to target the pristine ENMs, as done in the REACH guidance ("Regulation concerning the Registration, Evaluation, Authorisation and Restriction of Chemicals" [21], but the specific formulation of the ENM comprising e.g., coatings or adherent parts of the matrix they have been embedded in [22].

In addition to health impacts, ENMs may-analogously to UFP-also have implications on global climate if used in huge amounts. Especially, secondary UFP formed by oxidation of $\mathrm{SO}_{2}, \mathrm{NO}_{x}$ or VOCs to $\mathrm{H}_{2} \mathrm{SO}_{4} /\left(\mathrm{NH}_{4}\right)_{2} \mathrm{SO}_{4}, \mathrm{HNO}_{3} / \mathrm{NH}_{4} \mathrm{NO}_{3}$ and secondary organic aerosols (SOA) followed by nucleation or condensation processes (e.g., $[23,24]$ ) are important for climate due to their impact on atmospheric chemistry, cloud formation and the radiation budget of the earth (e.g., [25]).

The majority of the literature dealing with fate and transformation processes of ENM in the environment focuses on aquatic systems and soils (e.g., [26,27]), since the major part of ENMs is known to end up in these two compartments, whereas only $0.1-1.5 \%$ of produced ENMs are estimated to be released into the atmosphere during their life cycle [28]. Calculations conducted in studies by Gottschalk et al. [29] resulted in concentrations of several pg of ENMs $/ \mathrm{m}^{3}$ in the Danish atmosphere, whereas Müller and Nowack [30] modelled quantities of $1.7 \mathrm{ng} / \mathrm{m}^{3}$ nano- $\mathrm{Ag}, 1.5 \mathrm{ng} / \mathrm{m}^{3}$ nano- $\mathrm{TiO}_{2}$ and $1.5 \mathrm{ng} / \mathrm{m}^{3}$ carbon nanotubes (CNT) for the atmospheric compartment above Switzerland (realistic release scenario based on substance flow analysis), respectively. Though, no concentrations are published which are measured around production facilities where higher concentrations can be expected. In any case, monitoring concentrations, transformation processes and fate of airborne ENMs is relevant as atmospheric transformations can have a crucial impact on ENM's role in atmospheric chemistry and further fate in the environment [5]. In addition, most importantly, altered ENM characteristics caused by these processes may influence the toxic potential [31-34].

We currently lack sufficient knowledge of the types, rates, and extent of transformations expected for ENMs in environmental and biological systems [35,36]. Especially cross-media effects (i.e., transformations in the atmosphere that may affect fate in the aquatic or terrestrial environments or vice versa) have been largely overlooked in discussions of the environmental impacts of ENMs [37], but making predictions about ENM's fate, transport, toxicity and implications on atmospheric chemistry requires significant, multidisciplinary advances [38,39].

Part of the ENM transformation occurs shortly after release and depends on the ambient aerosol. Therefore it is highly important to be precise on the state in which ENMs are released, and in practical cases emission preprocessors may be necessary to account for such transformation processes close to the source before emissions can be used in models.

This review summarizes the current state of knowledge with regard to the emission, transformation, transportation and possible implications of ENMs in ambient air, to give an overview of which information is already present and which aspects might need further investigation. 


\section{How Can ENMs Be Released and How Much Is Emitted into Ambient Air During the Whole Life Cycle?}

So far most published measurement campaigns concentrated on assessing workers' exposure by measuring or calculating ENM concentrations in air at the workplace [40-42] whilst there has been little study of the release of engineered nanomaterials to the environmental air compartment during the product life cycle. Indeed, field measurements of ENMs in the environment are scarce and often measurements of releases of ENMs to air from industrial plants are done by the industry under strict confidential conditions. The following section aims at detailing the current knowledge of the various release scenarios that can lead to emission of ENMs to ambient air.

\subsection{ENM Life-Cycle}

Each step of the ENM life cycle from production, processing and use to the end-of-life (Figure 1) may lead to emissions into ambient air [43]. The emissions can be continuous, e.g., resulting from the evacuation of polluted air flows from production, transformation or waste treatment plants, the emission from the secondary material being processed (e.g., release from various matrixes following mechanical, thermal, chemical or combined stresses) either during the production of ENMs or during their use. ENMs can also be released accidentally, resulting from a sudden uncontrolled loss of containment, a fire or an explosion [44,45].

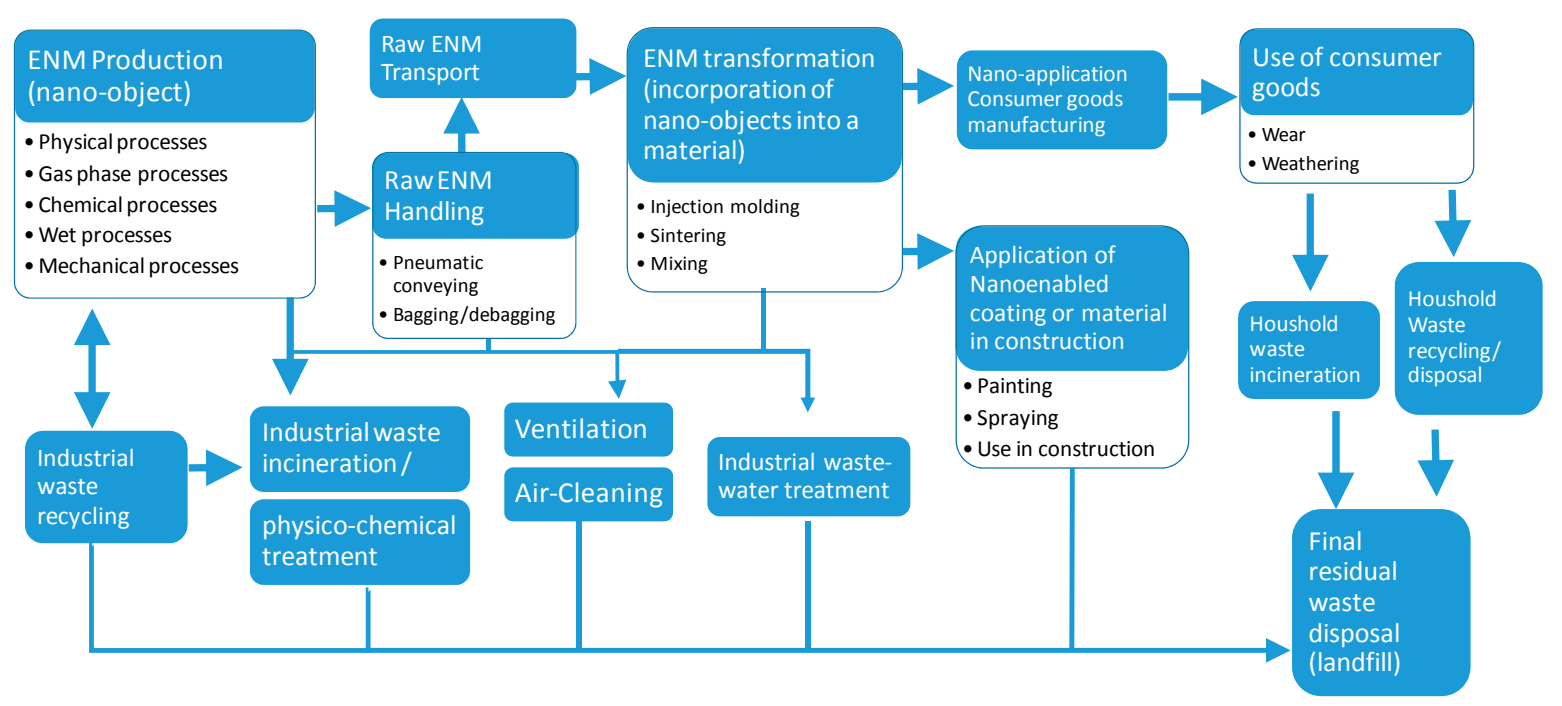

Figure 1. ENM life cycle.

An overall estimate of ENM release to different compartments by Keller et al. [28] considers that currently, around $63-91 \%$ of the ten most produced ENMs are disposed in landfills, whereas releases into water are around $0.4-7 \%$ of total global production. Air emissions represent the smallest flow to the environment for the studied ENMs, with an estimate of less than $1.5 \%$ of production when considering the highest release estimates. Yet, considering the potential impact of these emissions at the local scale and the major concerns about the potential health effects of ENMs when inhaled, the relative significance of the emissions to air should not be underestimated. At the local scale, emissions to air may become the major concern both with respect to environmental impacts and human health.

\subsection{Production of ENM: A Qualitative Overview}

Gottschalk and Nowack [46] estimated in 2011 as an initial approach from 0 to $2 \%$ release to the environment during manufacturing. More recently a study produced as support for 3rd regulatory review on nanomaterials for European Commission DG Environment has proposed updated emission 
factors during manufacturing [47] yet still mostly based on expert judgement ranging from $0.7 \%$ to $1.6 \%$ of which $6 \%$ is estimated to be emitted through air.

There exists a variety of ENM manufacturing processes with very variable emission potential. In many cases, the major emissions are not stemming from the process step generating the nanomaterial, but at a subsequent phase such as recovering particles from the reactor, milling, drying or further handling. Indeed, several production processes are closed as they are based on the chemistry of gas mixtures sometimes under low or high pressure. Other processes such as spray drying or milling are more prone to leaks as they are often performed in air at atmospheric pressure conditions.

The emission potential is also dependent on the form of the ENMs, i.e., whether it is produced as free powder, suspension in a liquid or already as solid material (e.g., master batch). Powders have a higher emission potential than suspensions or undivided solid forms.

As an illustration, Table 1 lists a series of ENM production processes [48] and indicates whether the process is potentially highly emissive [49]. The classification is qualitative and mainly based on expert judgement considering the intrinsic degree of tightness of the reactor in which the main chemical synthesis reaction occurs. It is considered here that synthesis reaction that require vacuum or controlled atmosphere are intrinsically less emissive during the synthesis phase, to the work environment and ambient air, than processes performed under atmospheric conditions. Yet it is important to underline the fact that tightness can always be reinforced to limit exposure and that opening a closed reactor to recover the produced particles or clean the reactor can be a source of emission. Emission control systems can also be added to reduce releases at each step of the process [50-53]. More precise figures on measured emissions from manufacturing processes in work environment can be found in [54] supporting the high variability of emissivity and the dependence on activities and processes involved as well as engineering controls in place.

Table 1. ENM production processes and their potential emissivity in the absence of controls: $\mathrm{H}=$ potentially high emissivity during the production phase, $\mathrm{L}=$ Low emissivity in normal conditions during the production phase.

\begin{tabular}{|c|c|c|c|}
\hline Process Type & Process & Production Conditions & Emissivity \\
\hline \multirow{2}{*}{$\begin{array}{l}\text { Physical } \\
\text { processes }\end{array}$} & \multirow{2}{*}{$\begin{array}{c}\text { Electrospinning } \\
\text { Gas phase processes based on } \\
\text { Heating and fast cooling }\end{array}$} & Closed & $\mathrm{H}$ \\
\hline & & Controlled atmosphere & $\mathrm{L}$ \\
\hline \multirow{5}{*}{ Chemical processes } & Laser pyrolysis & Controlled atmosphere & $\mathrm{L}$ \\
\hline & Spray drying & Atmospheric conditions & $\mathrm{H}$ \\
\hline & $\begin{array}{l}\text { Liquid phase processes: } \\
\text { precipitation, sol gel, exfoliation, } \\
\text { sonochemistry }\end{array}$ & $\begin{array}{l}\text { ENM produced as liquid } \\
\text { suspension; in case of } \\
\text { drying, it can be emissive }\end{array}$ & $\mathrm{H}$ \\
\hline & Chemical vapor deposition & Controlled atmosphere & $\mathrm{L}$ \\
\hline & Flame synthesis & Atmospheric conditions & $\mathrm{H}$ \\
\hline \multirow{4}{*}{$\begin{array}{c}\text { Mechanical } \\
\text { processes }\end{array}$} & Hot plasma synthesis & Controlled atmosphere & $\mathrm{L}$ \\
\hline & High energy milling & Atmospheric conditions & $\mathrm{H}$ \\
\hline & Severe plastic deformation & Atmospheric conditions & $\mathrm{H}$ \\
\hline & Shock wave processes & Atmospheric conditions & $\mathrm{H}$ \\
\hline
\end{tabular}

\subsection{Internal Handling and Transport of ENMs}

After being produced, the ENM will be handled. Internal transport and handling within the plant, including packaging operations, can be very important sources of accidental or continuous ENM emissions. For instance, pneumatic transport involves the movement of particles in an air flow from which they need to be separated by filters. Depending on the efficiency of this separation process, emissions can occur to the environment. Additionally, accidental loss of containment due to a breach or the piercing of a filter can lead to a spillage and air transport of particles. Falling of powder into a hopper or filling of a big bag are also potentially emissive processes [42]. 
However, certain measures have been developed to reduce ENM emissions in the workplace, such as containment or ventilation and air treatment [40,51].

\subsection{Emission from Stacks}

The main point sources at production plants are emissions from stacks which either stem from process flows from reactors and process units, or ventilation flows from working areas or specific working steps. Usually, process flows carry much more particles than workshop ventilation flows. The rate of emission is highly dependent on the rate of emission from processes, either directly to process flow or indirectly to the ambient air in the premises, and the efficiency of filtering devices used to prevent emissions to the environment in collecting nanoparticles. EN 1822-1 Standard [55] specifies the filtration efficiency for a variety of particle filters used in ventilation and climatization systems ranging from 85\% for EPA E10 filters up to $99.999995 \%$ for ULPA U17 filters. The filtration efficiency is measured at the "Most Penetrating Particle Size", which is determined specifically for each filter, ranging usually between $0.1 \mu \mathrm{m}$ and $0.5 \mu \mathrm{m}$ [56,57]. Collection efficiencies varying from $90 \%$ to $99.999 \%$ were reported for fabric filters used in municipal solid waste incineration plants with a minimum efficiency around $0.4 \mu \mathrm{m}$ [58].

\subsection{Diffuse Emission from Building}

If the ventilation and air cleaning of buildings is not efficient enough, diffuse emissions can also occur from the buildings through openings such as doors or windows. Such fugitive emissions were observed and documented for microscale $\left(\mathrm{PM}_{10}\right)$ particles in conventional industrial activities such as steel production [59] and ceramic industry [60]. Monfort et al. [60] determined for ceramic industry that if the appropriate corrective measures are applied, high efficiencies can be achieved in reducing $\mathrm{PM}_{10}$ diffuse emissions from the storage, handling, and transport of raw materials, particularly in semiclosed and closed facilities, in which the overall efficiency obtained was $75-80 \%$ and $>95 \%$, respectively. In such closed facilities emission factors between 7 to $11 \mathrm{~g}$ of $\mathrm{PM}_{10}$ per ton of product were estimated. So far, such a study still needs to be undertaken for the production and transformation of ENMs.

Material deposited on the ground by accident (leak, accidental spillage during handling) can remain in place for some time and be resuspended to form a new continuous emission.

\subsection{ENM Emissions during Manufacturing and Processing of Composite Materials}

There is a wide variety of ENMs. Their most frequent application involves the incorporation of nanoobjects into matrix material (polymer, ceramic or metal) to form a composite. The processes and the associated handling operations are potentially emissive, especially if the nanoobjects are incorporated as powder. The most common process for their incorporation in polymers is injection molding, but other processes such as spray-drying can also be used. The impact is usually limited to the workplace, although, due to improper filtration of local ventilation, particles might also be conveyed to the surrounding environment. Nowack et al. [61] described nine release scenarios along the lifecycle of a CNT bearing nanocomposite. The first one concerns the manufacturing of the material by injection molding. The second is relative to the processing of the composite material (cutting, sawing, drilling and sanding of raw nanocomposites). Machining operations like sanding, cutting and drilling are based on high energy input and may lead in each case to a considerable generation of ENMs in workplaces [61]. Unfortunately, these scenarios are only described in a qualitative way and quantitative estimates are lacking.

As for the initial manufacturing, engineering controls can lower the emission rates from plants in which these operations take place.

\subsection{Continuous Emission Rates from Industrial Plants}

Emission rates from industrial plants are rather difficult to apprehend due to the variety of industrial processes and industrial plant configurations. They are all the more difficult for ENMs 
as there is no specific dedicated regulation that imposes the measurement and declaration of ENM releases to the environment.

The IED directive is the European framework for the control of industrial emission. As far as particle emissions into air are concerned, the IED directive only focuses on $\mathrm{PM}_{10}$ and $\mathrm{PM}_{2.5}$ [62]. The IED directive requires plants to use best available technologies (BAT) in their processes to minimize the impact on the environment. Separately from the IED, the UNECE Convention on Access to Information, Public Participation in Decision-making and Access to Justice in Environmental Matters (better known as Aarhus Convention) grants the public rights to access environmental information. Under this Convention, the European Pollutant Release and Transfer Register (E-PRTR [63],) was established through Regulation (EC) No 166/2006 where pollutant emitters above a certain threshold have to report annually their pollutant release to air and to water. For particulates, only $\mathrm{PM}_{10}$ is required for reporting in E-PRTR, and ENMs are not considered at all. Although included in $\mathrm{PM}_{10}$, their emission rate cannot be deduced from $\mathrm{PM}_{10}$ data.

France was the first country to impose a declaration of the amounts of produced or imported ENMs [64]. Since the beginning of this legal requirement three annual reports were published with a progressive increase of the declaration rate. The total amount of ENMs declared as produced in France in 2014 [65] was 300,822 t. The total amount of ENMs declared as imported was 114,951 t. Table 2 presents the main categories of ENMs produced or imported in France in 2014. Due to confidentiality rules applicable to the use of declarations, only the broad tonnage interval is displayed. It is important to note that some ENMs of concern such as carbon nanotubes, although present in the declaration data, do not appear in this table because it presents only the ENM produced or imported in amounts above $100 \mathrm{t}$. In total, more than 300 different chemical species were identified among the declarations.

Table 2. Ten categories of ENM produced or imported in France in amounts higher than $1000 \mathrm{t}$ [65].

\begin{tabular}{cc}
\hline Generic Name & Tonnage Band \\
\hline Carbon black & $>100,000 \mathrm{t}$ \\
Silicon dioxide & $>100,000 \mathrm{t}$ \\
Calcium carbonate & $10,000-100,000 \mathrm{t}$ \\
Titanium dioxide & $10,000-100,000 \mathrm{t}$ \\
Boehmite (Al(OH)O) & $1000-10,000 \mathrm{t}$ \\
Vinylidene chloride copolymer & $1000-10,000 \mathrm{t}$ \\
Silicic acid, magnesium salt & $1000-10,000 \mathrm{t}$ \\
Aluminium oxide & $1000-10,000 \mathrm{t}$ \\
Vinyl polychloride & $1000-10,000 \mathrm{t}$ \\
Mixture of cerium dioxide and zirconium dioxide & $100010,000 \mathrm{t}$ \\
\hline
\end{tabular}

Although these data improve greatly the vision of the ENM market, they do not directly inform on release rates. The published data do not allow to differentiate the forms in which the ENM is produced: powder, suspension in a liquid or in a solid, nor do they mention the production and transformation process. Yet they can be used in a first approach to identify the ENMs present on the market in large quantities and have been used in [47] as a basis to estimate global releases by nanomaterials family.

\subsection{Emission During Use}

During the ENM use phase, particles embedded in a matrix material can be emitted due to abrasion induced by the user or material degradation under various types of ambient solicitations (rain, wind, sun). Such phenomena have been studied for a variety of materials, such as construction materials [66], composites [67,68] and surface coating [69,70]. Also, some reviews on release mechanisms [71,72] and on protocols simulating aging are available [73]. The emission rate is highly variable and depends on the ENM and on the conditions of use. Values ranging from 0 to $90 \%$ release of the ENM to the environment have been estimated by Keller et al. [28], with only low fractions (0-5\%) of these values released into air. For most ENMs the use phase is the most important source of ENM 
release to the environment, however release to air is only a small fraction of this (e.g., [29]). Therefore, far, although several authors have developed conceptual and computational material flow analysis models, reliable data are missing to estimate the release rate from objects containing ENMs during their use phase [43].

\subsection{Transportation of ENM}

During transportation, if proper packaging is used, the risk of emission is mostly accidental. Yet, so far there is no specific requirement regarding the transportation of ENMs. Decisions are based on requirements applicable to any powder material and depend mainly on proven hazardous properties determined through regulatory testing. Thus, it cannot be ruled out that transportation of ENMs is done in a way that allows for particles to be emitted.

At least one road accident involving spilling of ENM $\left(\mathrm{TiO}_{2}\right)$ powder was reported [45]. This accident occurred when big bags fell on the road due to improper tightening of the truck load. However, it is possible that several others occurred and were not identified as such due to the absence of specific labeling of nanomaterials.

The emission that results from a transportation accident is difficult to assess. It is partly composed of a first emission due to the shock and initial loss of containment, but it is then followed by a continuous lifting by air of particles from the spill until the spill is completely cleaned-off.

\subsection{Emission into Air during Waste Treatment and Disposal}

Various waste treatment technologies can be envisaged for ENMs such as recycling, landfill disposal, and incineration. The emission of ENMs from incineration has been studied in various projects [74,75]. Ounoughene et al. [76] showed that the fate of ENMs is highly dependent on their composition. Carbonaceous and organic ENMs have a tendency to burn and therefore to be completely eliminated. Other ENMs such as nanoclays were shown to remain in the combustion residues [75]. When burning silicone polymers with a $\mathrm{SiO}_{2}$ load, nanoparticles were found in the fly ashes, but it was concluded that a large part of these particles were in fact the result of the silicon combustion and not only the release of the incorporated ENMs [76]. Most of these particles can be collected by usual smoke treatment processes in state of the art incinerators.

In a quantification approach Mueller and Nowack [30] estimated rates of release from waste incineration plants of $0.05-1 \%$ into air, $1-50 \%$ into slag, and $50-98 \%$ being captured by filters. For comparison, waste water treatment plants are estimated to remove between $75 \%$ and $97 \%$ of ENMs from the inflow waters $[77,78]$ and transfer them to biosolids which are then disposed off through incineration, application to agricultural land, or landfills.

\subsection{Emissions during Abnormal Conditions along the Life Cycle: Accidental Release}

Beside continuous emissions, incidents or accidents can also lead to significant emissions. The main scenario is an accidental or at least unwanted loss of containment which results in a flow of particles in the air, which will directly be transported to the surrounding environment or will form a depot on the ground that will be resuspended and transported until the spill is removed. Fire and explosions can also be the cause of emission of ENMs to air. In terms of quantity, the amount of ENMs released to the environment during one single accidental event could, in some cases, exceed the continuous emissions from plants, especially when very stringent measures are applied to limit continuous emissions.

\section{How Can ENMs Be Transformed during the Airborne Phase?}

While a lot of research has been done on transport and alterations of ENMs in aquatic media during the last years, information on ENM transformations within the atmosphere is still quite scarce. However, information and studies about the emission and behavior of unintentionally produced UFP are readily available, which can be used as starting point for the ENM assessment. While 
engineered nanomaterials consist of primary particles, UFP can be released as primary particles (e.g., soot) or can be formed in the atmosphere as secondary particles from gaseous precursors (e.g., formation of $\left.\left(\mathrm{NH}_{4}\right)_{2} \mathrm{SO}_{4}\right)$. Modest differences between the characteristics and behavior of atmospheric ENMs and UFP have been observed, originating from the higher ENM uniformity in shape, size and functionality [79]. However, projecting knowledge of UFP behavior on ENMs seems to be justified in most cases. In some cases, though, there can be significant discrepancies when e.g., ENM cannot coagulate due to specific surface functionalities like coatings [80].

We can differentiate between the physical transformation processes of hetero- and homo-coagulation and condensation, physico-chemical dissolution as well as chemical transformation processes such as oxidation or chemisorption during cloud processing and photo-induced reactions that might result in removal of coatings and change from hydrophobic to hydrophilic behavior. Usually, the fate of ENMs is affected by a combination of several of these processes.

\subsection{Physical Transformations}

\subsubsection{Coagulation}

Generally, particles in the nanometer size range tend to coagulate due to their large diffusion coefficients. However, since the coagulation rate for simple monodisperse coagulation (homo-coagulation) is proportional to the square of the particle number concentration [81], this process is negligible at low concentrations of ENMs. For example, Maynard and Kuempel [82] calculated that nanometer-diameter particle concentrations below $10^{12}$ particles $/ \mathrm{m}^{3}$ can be assumed to be relatively stable in an occupational environment. Due to the diminutive atmospheric concentrations of ENMs (e.g., [30]), homo-coagulation seems to be negligible in the atmosphere. This process could be important at higher concentrations found in accidental industrial releases or potentially occurring near the emission source, e.g., close to production lines. However, homo-agglomerates might be formed in local environments with higher concentrations and persist at a background scale, as predicted by Quik et al. [83] for aqueous media.

Polydisperse (hetero-)coagulation is enhanced when small particles with their high diffusion coefficients diffuse to a large particle with its large surface area [84]. Hetero-coagulation is therefore most effective for particles of different sizes. Hence, hetero-coagulation is assumed to dominate over homo-coagulation between ENMs in the atmosphere, as shown for example by Seipenbusch et al. [85], who conducted experiments in an aerosol chamber to investigate the agglomeration behavior of metallic nanoparticles (Pt). They simulated background aerosol by introducing appropriate concentrations (typically $\sim 10^{3}$ to $10^{4} \mathrm{~cm}^{-3}$ ) of oil droplets and monodisperse silica particles (particle sizes in the range of $0.1-1 \mu \mathrm{m}$ ) and found almost the entire primary ENM peak to vanish by attachment onto the larger background particles.

It is important to keep in mind that although the particle number concentration is diminished by coagulation, the ENM itself is not removed from the atmosphere. However, the change in size of the particle does have an impact on the lifetime of the ENM as discussed in Section 3.1.4.

In aquatic media polymeric-like molecules such as humic substances may be capable of imparting strong electrostatic charges or steric stability to the surface of ENMs preventing coagulation upon sorption [86,87]. Although there has been some work on humic-like substances [88], there have been no studies to assess if the presence of large organic molecules in the atmosphere can play a similar role.

\subsubsection{Condensation}

Airborne particles down to ca. $40 \mathrm{~nm}$ may act as nuclei for the condensation of water and semi-volatile compounds-most frequently sulfate, nitrate, ammonium and organic compounds. For UFP typical particle growth rates in the range 1-20 $\mathrm{nm} \mathrm{h}^{-1}$ have been identified by Kulmala et al. [24] in mid-latitudes depending on the temperature and the availability of condensable vapors. 
Once released into the atmosphere, ENMs might also serve as condensation nuclei. Their condensational growth is generally assumed to occur within a similar time frame. However, this property depends not only on particle size, but also on surface characteristics meaning that these processes may be hampered by particular surface coatings.

In a study performed by Lee and Donahue [89] the authors showed that polyacrylic acid coatings on $\mathrm{TiO}_{2}$ and $\mathrm{CeO}_{2}$ nanoparticles act as retardant for secondary organic aerosols, generated from $\alpha$-pinene ozonolysis under atmospheric conditions. This assumption is confirmed by studies relating measurement efficiencies of Water-Based Condensation Particle Counters (WCPC) to those performed by butanol-based Condensation Particle Counters (CPC) which revealed lower counting efficiencies for some hydrophobic types of particles, such as candle-generated aerosol (paraffin) and emery oil [90], as well as for Di(2-ethylhexyl) sebacate (DEHS) particles [91]. Therefore it can be assumed that such kinds of ENMs or ENMs coated with hydrophobic substances might exhibit lower atmospheric growth rates.

In addition to particle enlargement, condensation processes can also cause ENMs to get more spherical, e.g., due to compaction of the agglomerates, as shown for soot particles by Slowik et al. [92]. This is especially relevant for CNT, since their aspect ratios might be significantly reduced during condensation, resulting in modified behavior in the environment.

Some case-studies highlighting exceptional coagulation-properties of particular ENM have been published so far. Tiwari and Marr [37] compiled such literature focusing on atmospheric transformations of $\mathrm{C}_{60}$ fullerenes and CNT. They suspect fractal and non-spherical ENMs, such as aggregated fullerenes and tangles of $\mathrm{CNT}$, to convert to more spherical structures during atmospheric processing, due to analogous findings in laboratory experiments for fractal agglomerates of carbon particles exhibiting branched chains (e.g., [93]).

\subsubsection{Dissolution}

Solubility of ENMs depends not only on solvent characteristics such as ionic strength, saturation state, $\mathrm{pH}$, etc. [94], but also on several parameters of the particles themselves, such as size, surface, shape and aggregation. Atmospheric particles are known to traverse multiple condensation cycles [95] influencing their dissolution behavior: Laboratory experiments conducted by Desboeufs et al. [96] and Spokes et al. [97], in which evaporation chambers have been applied to simulate cloud processing, revealed elements dissolved during each condensation/evaporation cycle (e.g., aluminum, iron, and manganese), to deposit back on the surface possessing an altered structure increasing their dissolution within the next cycle. Desboeufs et al. [96] state this mechanism to depend strongly on pH of the aqueous phase, which can in turn be influenced by the particle itself. Consequently, dissolution of particles (including ENMs) within the atmosphere is not straightforward.

Nevertheless, some progress in tackling this problem has already been made. For instance, Kaptay et al. [98] concentrated on the impacts of size and shape of ENMs on their solubility, and by Mihranyana and Strømme [99] investigating dissolution behavior of fractal ENMs. Furthermore, Quadros and Marr [100] referring to a study by McMahon et al. [101] assume Ag-nanoparticles to dissolve into cloud or fog droplets under slightly acidic conditions, releasing silver ions. Apart from silver, dissolution of iron and zinc oxide ENMs was observed within aqueous media and might also occur at high humidities within air, releasing $\mathrm{Fe}^{2+}, \mathrm{Fe}^{3+}$ [102], and $\mathrm{Zn}^{2+}$ [103] whereas the frequently applied $\mathrm{TiO}_{2^{-}}, \mathrm{SiO}_{2}$-ENMs as well as unfunctionalized fullerenes and CNT exhibit very low solubilities [28,104,105].

\subsubsection{Removal from Atmosphere}

ENMs will ultimately deposit on soil or surface water [106] by dry or wet deposition. This deposition may either happen directly or follow growth of ENMs via coagulation and/or condensation.

According to Seinfeld and Pandis [107] the vertical dry deposition flux is dependent on local particle concentration in a specific height over the ground, since it does not act on the full column 
(except for gravitational settling of large particles) but is related to processes close to the earth's surface where it includes turbulent diffusion and collection of particles by surface and vegetation. The efficiency of dry deposition is relatively high for small particles and for high friction velocities [81]. Removal reaches a minimum for a particle size range of 100 to $1000 \mathrm{~nm}$ resulting in extended atmospheric lifetimes for ENMs that have grown into this size range or are attached to larger co-emitted particles [37].

Within regions of precipitation, wet deposition (scavenging by precipitation elements) can be the dominant removal process. Wet deposition depends on the amount, type and intensity of the precipitation and on the properties of the scavenged material. For aerosols, the scavenging coefficient is dependent on the particle size and other particle properties (for example, whether the aerosol is hydrophilic or hydrophobic).

For all these deposition processes, theoretical frameworks exist but uncertainties are large. Measurements on dry and wet deposition and deposition velocities only cover a limited set of atmospheric conditions and both measurements and the theoretical framework show uncertainties of a factor 10 to 100. Deposition of UFP has been investigated in some case studies, e.g., [108,109], who conducted experiments within test chambers to determine deposition rates of $\mathrm{NaCl}$ particles and gasoline vehicle exhaust, respectively.

\subsection{Chemical Transformations}

Literature on chemical transformation of ENMs within the atmosphere is scarce and within the existing studies most authors concentrated on a single type of nanomaterial $[9,110,111]$. Generally, chemical transformation affects the ENM's surface first and might even be restricted to the outer layer depending on chemistry of the particles themselves and of the coating if present. These implicated alterations of surface chemistry are most important, since they can influence the fate of the particle in the environment. Most prominently, oxidation processes or photo-induced chemical reactions may result in active sites on particle surfaces to be passivated or coated with time [18,82]. For instance, gas-phase oxidation of carbonaceous particles is known to cause an increase in hygroscopicity [112], and other atmospheric processes, such as condensation of organic molecules or the incorporation of carbonaceous particles into internally mixed aerosols, might have similar impacts [37] potentially influencing ENM's fate and transport within the atmosphere.

\subsubsection{Oxidation in Ambient Air}

Upon release into the atmosphere metallic ENMs, such as nano-iron or nano-silver, are transformed via chemical reactions with atmospheric oxidants $[113,114]$, whilst common nano-oxides such as $\mathrm{TiO}_{2}, \mathrm{SiO}_{2}$ and $\mathrm{CeO}_{2}$ will not undergo further oxidation after being released into the atmosphere.

Atmospheric organic aerosols are well known to be oxidized by reactions with hydroxyl radicals, ozone, and other oxidants, leading to the formation of oxide, carbonyl, hydroxyl, carboxylic acid, and other functionalities that make the particles more hydrophilic [115]. First studies have proven that the same seems to apply for carbonaceous ENM [37].

For instance, Tiwari et al. [116] investigated reactions between aerosolized fullerenes $\left(\mathrm{C}_{60}\right)$ and $\mathrm{O}_{3}$ at atmospherically relevant $\mathrm{O}_{3}$ mixing ratios with reaction rates ranging from $9 \times 10^{-6}$ to $2 \times 10^{-5} \mathrm{~s}^{-1}$. Results indicate that $\mathrm{C}_{60}$ is oxidized by $\mathrm{O}_{3}$ and forms a variety of oxygen-containing functional groups on the aerosol surface, which are expected to reduce hydrophobicity of the material, since this effect was observed for studies of the same reaction within aqueous media [117]. Additionally, the authors found the extent of this reaction to be influenced by relative humidity (surface oxygen content rises with relative humidity), whilst kinetics may be influenced by photolysis (see section "Photo-induced reactions").

So far, ambivalent results have been published concerning the reactivity of $\mathrm{CNT}$ with $\mathrm{O}_{2}$. Collins et al. [118] found CNT exposure to air or oxygen to dramatically influence their electrical 
resistance, thermoelectric power, and local density of states, as determined by transport measurements and scanning tunneling spectroscopy. Giannozzi et al. [119] report triplet oxygen to retain its spin-polarized state when interacting with a nanotube leading to the formation of a weak physisorptive bond with essentially no charge transfer between the molecule and the CNT.

A possible explanation for these ambivalent results is provided by Goldoni et al. [120], who performed investigations of single-wall CNT processed in buckypaper using Electron Energy Loss-Spectroscopy (EELS). They revealed the presence of residual contaminants in purified SWCNT to be possibly responsible for their claimed sensitivity to oxygen. However, the authors cannot rule out for sure that their treatment of SWCNT at high temperatures under ultrahigh-vacuum conducted for purification purposes might have induced the insensitivity of the CNT towards $\mathrm{O}_{2}$.

\subsubsection{Reactions with Other Substances Apart from Oxygen}

To identify and quantify possible transformation processes affecting nano-silver, McMahon et al. [101] measured surface plasmon-polariton spectra upon exposure to laboratory air. They observed sulfur to be chemisorbed at the surface of the particles and determined a growth rate of this tarnishing product $\left(\mathrm{Ag}_{2} \mathrm{~S}\right)$ of $3 \mathrm{~nm}$ per day, being 7.5 times higher than that of bulk $\mathrm{Ag}$ under the same conditions. Consequently, atmospheric nano-silver might be assumed to transform even more quickly, since larger parts of the ENM's surface area are expected to be exposed to air compared to the experimental setup by McMahon et al. [101], where particles were placed onto a substrate.

In a study performed by Goldoni et al. [120] that has already been described briefly in the previous section, chemical alterations of SWCNT due to reactions with $\mathrm{NH}_{3}, \mathrm{NO}_{2}$ and $\mathrm{SO}_{2}$ were confirmed to take place, whereas no changes in electronic spectra of "clean" SWCNT were observed after exposure to $\mathrm{O}_{2}, \mathrm{CO}, \mathrm{H}_{2} \mathrm{O}$ and $\mathrm{N}_{2}$, indicating that these gases interact with clean SWCNT via weak London dispersion forces only.

\subsubsection{Photo-Induced Transformation Processes}

Apart from chemical reactions such as oxidation, certain ENMs can be photoactivated upon exposure to light of specific wavelengths [82]. This photoactivation can result in photolysis, photooxidation or photoreduction, which can act to change the structure and properties of ENMs [18].

Probably the most prominent example for photo-induced reactions are $\mathrm{TiO}_{2}$ particles: Depending on the type of $\mathrm{TiO}_{2}$ applied (photoreactive or photostable), photochemical transformation on the surface of $\mathrm{TiO}_{2}$ nanoparticles takes place due to its known photoreactivity (e.g., [22,121]) which is discussed in detail in Section 4.1.

For the aqueous phase photolysis of $\mathrm{C}_{60}$ clusters has been observed [122]. Since this process has been shown to depend on aggregation state, this transformation may be marginal in natural waters, but might play a major role in the atmosphere, where aggregation is less likely under typical conditions [37]. However, atmospheric processing and thus functionalization of $\mathrm{C}_{60}$ may influence fullerenes' potential for undergoing photolysis in the natural environment [37]. As mentioned by Tiwari et al. [116], photolysis may also influence the $\mathrm{C}_{60}-\mathrm{O}_{3}$ reaction in terms of rate, distribution of products, and/or reactive oxygen species (ROS) generation potential, suggesting that atmospheric transformation of $\mathrm{C}_{60}$ fullerenes would alter them substantially and may result in the introduction of highly oxygenated and cross-linked fullerenes into the environment. However, the extent to which photolysis of carbonaceous ENMs in the atmosphere may occur is unknown [37] since the study of photochemistry at interfaces, specifically the air-particle one, is still in its infancy [123].

Sunlight exposure might also represent one major pathway causing the loss of coatings, as sunlight-catalyzed redox reactions are suspected to be involved in the degradation of some polymeric coatings, such as gum Arabic, present on ENMs [124]. The loss of engineered polymeric coatings may inter alia induce instability and facilitate (hetero-)aggregation [18] and can thus alter the ENM's fate in the environment crucially. 


\section{What Are the Possible Atmospheric Implications of ENMs?}

Besides the effects the atmosphere has on ENM transformation, ENMs also might affect atmospheric chemistry and physics. Wiesner et al. [125] figured out that ENMs also show high absorption coefficients, and many of them can act as catalysts [80]. However, no information is currently available on the interactions between ENMs and the chemicals they absorb, and how this interaction might influence atmospheric chemistry.

\subsection{Photo-Catalytic Properties of $\mathrm{TiO}_{2}$}

As mentioned before, $\mathrm{TiO}_{2}$ owns special properties: When excited with light of wavelengths equal to or greater than the band gap energy ( 3.0 and $3.2 \mathrm{eV}$ equal to lights wavelength of 290 and $390 \mathrm{~nm}$ for rutile and anatase, respectively), electron hole pairs are generated in the conduction and valence bands, respectively (e.g., [126]). These electron-hole pairs can then follow several pathways: (i) recombination of electrons and holes on the surface or in the bulk of the semiconductor; (ii) reduction of electron acceptors by photogenerated electrons; and (iii) oxidation of electron donors by photo-generated holes $[127,128]$. As a consequence, $\mathrm{TiO}_{2}$ surfaces facilitate interfacial photochemical reactions and these reactions have the potential to change the chemical balance of the atmosphere $[129,130]$.

The formation of reactive oxygen species ( $\mathrm{ROS}$, e.g., $\cdot \mathrm{OH}, \mathrm{HO}_{2} \cdot, \cdot \mathrm{O}^{2-}$ ) is known to be catalyzed by $\mathrm{TiO}_{2}$ [131] and $\mathrm{ROS}$ again might also initiate additional photo-catalytic reactions, which is described as remote photo-process (e.g., [132]), or can get involved in redox-reactions with other atmospheric constituents, such as VOC (e.g., [133]). Accordingly, adsorption of $\mathrm{VOC}$ on $\mathrm{TiO}_{2}$ surfaces and subsequent degradation into $\mathrm{CO}_{2}, \mathrm{H}_{2} \mathrm{O}$, and other low-molecular weight compounds acts as a potential removal pathway.

$\mathrm{CO}_{2}$ and $\mathrm{SO}_{2}$ are known to adsorb on $\mathrm{TiO}_{2}$ surfaces resulting in formation of adsorbed $\mathrm{HCO}^{-}$[134] and adsorbed sulfite or sulfate (e.g., [135]), respectively.

$\mathrm{TiO}_{2}$ has been reported as an effective $\mathrm{NO}_{\mathrm{x}}$ removal material by reducing $\mathrm{NO}_{2}$ into gaseous $\mathrm{HONO}$ and minor amounts of $\mathrm{N}_{2} \mathrm{O}$ as well as into surface adsorbed $\mathrm{NO}^{-}, \mathrm{N}_{2} \mathrm{O}_{2}{ }^{2-}$, and under atmospheric conditions most frequently nitrate $[130,136]$. However, $\mathrm{TiO}_{2}$ has also been observed to produce $\mathrm{NO}_{\mathrm{x}}$ by photo-oxidation of Ammonia under atmospheric conditions [137]. Additionally, Monge et al. [138] revealed the production of $\mathrm{O}_{3}$ to be induced by $\mathrm{TiO}_{2}$ upon exposure to $\mathrm{NO}_{x}$ under illumination, and the deactivation of $\mathrm{TiO}_{2}$ surfaces by nitrate coating formation was observed ([130] and references therein) resulting in a more complex role of $\mathrm{TiO}_{2}$ in atmospheric chemistry than previously assumed.

Photo-catalytic decomposition of $\mathrm{O}_{3}$ on $\mathrm{TiO}_{2}$ under atmospheric conditions has been observed by various authors (e.g., [139]) and might represent an important sink of ozone in the atmosphere. By combining experimental observations with modeling studies, it has furthermore been suggested that heterogeneous removal of $\mathrm{H}_{2} \mathrm{O}_{2}$ by mineral dust aerosol may have a significant effect on tropospheric $\mathrm{HO}_{x}$ chemistry, $\mathrm{OH}$ budgets, and, consequently, ozone levels [130].

These processes are influenced by different parameters, such as relative humidity, concentration of reactants present, the relative binding of water versus reactants to the surface, and the mechanism of the photocatalytic reactions. Especially water plays a major role since apart from being involved in generating $\mathrm{OH}$ radicals by photo-chemical reactions on $\mathrm{TiO}_{2}$ surfaces, $\mathrm{H}_{2} \mathrm{O}$ can also act as inhibitor/promotor by blocking/establishing surface reactive sites for adsorption or reaction of reactant molecules on $\mathrm{TiO}_{2}$ particles [131]. For instance, Bedjanian and El Zein [136] investigated the interaction of $\mathrm{NO}_{2}$ with solid $\mathrm{TiO}_{2}$ films in a flow reactor via mass spectrometric and ion chromatographic detection and measured the following yield of the products of $\mathrm{NO}_{2}$ interaction with pure $\mathrm{TiO}_{2}$ under real atmospheric conditions: $0.65 \pm 0.10,0.05 \pm 0.05$, and $0.15 \pm 0.05$ for $\mathrm{HONO}, \mathrm{NO}$, and $\mathrm{N}_{2} \mathrm{O}$, respectively. The distribution of the products between $\mathrm{NO}$ and $\mathrm{HONO}$ was found to be independent of temperature in the range $\mathrm{T}=280-320 \mathrm{~K}$ and was governed by relative humidity $(\mathrm{RH})$ with an increase in $\mathrm{RH}$ leading to lower $\mathrm{NO}$ and higher $\mathrm{HONO}$ yield at a maximum of nearly $65 \%$ reached at $5 \%$ RH [136]. 
As implied by experiments conducted by Egerton and Mattinson [126], silica seems to block the photo-activity of $\mathrm{TiO}_{2}$, since they observed the photo-oxidation rate of propan-2-ol to be reduced when $\mathrm{TiO}_{2}$ particles were coated with silica compared to uncoated particles. Hence, Majestic et al. [113] conclude that a quick deactivation of $\mathrm{TiO}_{2}$ might take place in arid areas with high concentrations of wind-blown dust. However, this hypothesis is not confirmed by any study.

Although nanoscale $\mathrm{TiO}_{2}$ particles are representing only a small portion of the mass of PM, ENMs could contribute significantly to $\mathrm{TiO}_{2}$ in the atmosphere $[140,141]$ due to their widespread use (see Table 2). Despite lacking literature, $\mathrm{TiO}_{2}$ ENM particles are expected to display high photocatalytic activity due to their large surface area to volume ratios, potentially playing an important role in atmospheric chemistry. For instance, Auffan et al. [4] state that the anatase phase, which is greater for very small $\mathrm{TiO}_{2}$ particles, is more effective in the production of hydroxyl radicals and the subsequent decomposition of organic compounds than the rutile phase. This size-dependent photo-catalytic activity was not observed to increase monotonically with decreasing size but rather pass through a maximum significantly below $100 \mathrm{~nm}$ ([4] and references therein).

\subsection{Atmospheric Relevant ENM Other Than $\mathrm{TiO}_{2}$}

Although $\mathrm{TiO}_{2}$ is seen to be the most prominent example for ENMs influencing atmospheric chemistry, other ENMs might have impacts on the atmosphere as well. As the concentration of the different ENMs in the atmosphere is key, measurements are needed.

Inorganic ENMs other than $\mathrm{TiO}_{2}$ (e.g., $\mathrm{ZnO}$ ) and photosensitive fullerenes have also been associated with oxidative stress since light stimulation was proven to catalyze ROS production at the ENM's surfaces [141-144]. In addition to the ENMs that have been mentioned in the literature as affecting atmospheric chemistry, all substances being capable of producing ROS in the atmosphere or in water are assumed to be relevant. For instance, the ROS generation of nano-Au suspended in water has been shown upon exposure to X-ray and UV irradiation [145]. Further exemplary data on that topic can be found in Wohlleben et al. [73]. However, ENMs might also have the contrary effect regarding ROS: For instance, ceria ENMs have been shown to scavenge superoxide [146].

In addition, ENM can be involved in chemical atmospheric reactions not involving ROS. For example, Patakfalvi et al. [147] have shown $\mathrm{SO}_{2}$ to adsorb onto the surface of silver ENMs as well as the Ag catalyzed reduction of $\mathrm{NO}$ in aquatic media, which might also be relevant processes upon release into the atmosphere at high $\mathrm{RH}$.

\subsection{Other Effects of ENMs on the Atmosphere}

UFP are known to be important for climate studies as they can act as cloud condensation nuclei $(\mathrm{CCN})$ and therefore impact cloud formation and in consequence the radiation budget of the earth (e.g., [148]). This indirect radiation effect is also possible for ENMs. However, due to low ambient concentrations, the impact of ENMs is expected to be much lower compared to conventional particles.

In polluted air, light scattering by particles is relevant especially for those containing sulphate, organic carbon and nitrate species, whilst black carbon particles (e.g., soot from Diesel engines and coal combustion) are relevant for light absorption. Although particles $<100 \mathrm{~nm}$ are too small to be visible and thus do not directly interact with radiation, ENMs might have an impact for this direct radiation effect when being present as aggregates/agglomerates $>300 \mathrm{~nm}$.

Visibility impairment is generally caused by a build-up of suspended particles in the atmosphere. It increases with relative humidity and atmospheric pressure and decreases with temperature and wind speed [149]. At high relative humidity, the light scattering cross-sectional areas of particles enlarge by uptake of water. For an ammonium sulphate particle, the increase may be by a factor or five or more above that of the dry particle [150]. Light scattering may cause $60 \%$ to $95 \%$ and light absorption $5 \%$ to $40 \%$ of overall visibility reduction [151,152].

At this point in time, no further relevant implications that ENMs could exert on the atmosphere have been identified. 


\section{How Long Will ENM Stay in the Atmosphere, How Far Are They Transported and Where Deposited?}

Transport and deposition of species in the atmosphere have been studied intensively over the past 50 years. Drivers of these studies were concerns about air quality and nuclear safety. Most of the research was devoted to describing mass concentrations and deposition, and state-of-the-art chemistry-transport models describe ambient concentrations fairly well. Over the past ten years ultrafine particles have gained attention in view of health and climate effects. For these particles, nucleation, agglomeration and condensation have to be taken into account. Although this area of research can build on the expertise for conventional particles, several aspects for UFP are currently still described less accurately. This holds even more strongly for ENMs. On the other hand, modelling of atmospheric fate of ENM is less uncertain than environmental fate in water and soil systems.

As pointed out in Section 3 on ENM transformation, not much is known about the deposition behaviour of ENM and analogy is sought with ultrafine particles (UFP) from other origins. A difference between UFP and ENMs which may affect their removal rates is the fact that fresh ENMs may have more pronounced shapes (e.g., nanotubes, fibers). On the other hand, ENMs are quite often not released at nanoscale size but as larger aggregates so that they can be described as conventional particles with respect to wet and dry deposition. Ding et al. [40] have compiled an overview of ENM release at different workplaces, which can be used as a first estimate of ENM sizes. For most processes (cleaning, packing, sonication, mixing and spraying) ENMs are released as aggregates at sizes larger than $100 \mathrm{~nm}$ and mostly in the order of $1 \mu \mathrm{m}$. Only for machining and to a lesser extent production, ENMs were found to be released at particle sizes between 10 and $100 \mathrm{~nm}$. Another peculiarity for assessing the fate of particles is the accidental release of ENMs. Accidental release of nano-powders to air can happen by explosion, a fire or a major loss of containment, and is associated with high energy and high concentrations as compared to regular release during production, manufacturing and in the use and disposal phase described in chapter 2. Such scenario already occurred in France with carbon black being released from a pneumatic transport pipe after its rupture, leading to a massive jet release of nanomaterial [153]. This is the most critical scenario as the quantity of released ENMs is maximized. So far, literature studies concerning the modeling of massive release of powders are rather scarce and were devoted to the study of micropowders [154,155]. In order to fully understand the behavior of nanoparticles when they are released with high concentrations in a jet, observations and CFD-modelling including particle dynamics should be combined to identify contours of high concentrations and determine transformations in the state of the material.

For more general environmental fate assessment (production and use phase of material) lifetime and transport distance are dominated by deposition and transformations. Specific models are not yet available to simulate the spatial and temporal ENM concentration field in the air at a local to middle scale [76]. However, models predicting UFP concentrations on a regional scale (e.g., LOTOS-EUROS) are available. A problem is that the material is poorly classified at emission. Most important information needed for accurate fate description are size, attachment to other material, coating, reactivity, volumes, continuous or intermittent emission and the emission height.

Another difficulty to determine lifetime and transport distances of ENMs is caused by their wide variety of particles and release forms (release as raw material, tailpipe emission of motor oil additives together with UFP and condensables, or abrasion of ENM-containing material like tire and break wear), that undergo transformations in the atmosphere as described in Section 3. Properties also depend on concentration at release and presence and concentrations of co-emitted and ambient particles, and subsequent dilution. This means that it is necessary to explicitly investigate a specific material and release form in order to come to a quantitative expression on transport distances and life time, and these values cannot be simply extrapolated to other ENMs. Spatially resolved emission inventories with good characterization for such particles are still in their earliest phase (see Section 2) and are a prerequisite for spatially resolved concentration and deposition. 
Also the release height and vertical mixing play a role. In this paper, we only consider release and processes relevant for the atmospheric boundary layer, which will be the most relevant case for ENMs (surface emissions from traffic, abrasion of materials and low stack emissions from plants).

\subsection{Study Results on Atmospheric Processes Influencing Fate of UFP}

\subsubsection{Near-Source Processes: Coagulation Versus Dry Deposition}

As already mentioned in Section 3.1, both, coagulation (especially hetero-coagulation) and dry deposition are explicitly relevant and competing processes regarding the fate of ENM. Close to the source, relatively high concentrations of particles may lead to rapid particle growth due to coagulation. On the other hand, deposition velocities for the smallest particles are relatively high. The balance between the two is important to determine the lifetime and transport distances. Since both processes lead to a decrease in number of particles they are difficult to separate in field observations. Here we present results from field studies of UFP as an indication for ENM behavior.

In particular traffic exhaust emissions have been the subject of several recent studies that are relevant here, for their general conclusions regarding behavior of UFP right after release, but also with respect to emissions of e.g., motor oil additives that may be co-emitted. Ketzel and Berkowitz [156] conclude for exhaust emissions that deposition is faster than coagulation for particle sizes $>50 \mathrm{~nm}$ while coagulation is faster for smaller particle sizes in their modelling study. Karl et al. [157] performed a modelling study with aerosol dynamics (MAFOR model) for traffic emissions and compared results to observations in various cities. Dry deposition and coagulation of particles were identified to be the most important aerosol dynamic processes that control the evolution and removal of particles. However, CFD calculations on a street canyon for different wind directions by Nikolova et al. [158] revealed that the overall effect of deposition and coagulation on the UFP is negligible for the cases considered. They conclude that overall, deposition is more efficient and faster than coagulation in removing particles, and especially those in the nucleation mode. Choi and Paulson [159] performed a field study on freshly emitted vehicle exhaust particles in an early-morning experiment, at a time at which dilution has a smaller (but still dominant; $70-80 \%$ ) impact on particle concentrations. They observed that concentrations in the smaller size bins $(5.6-23.7 \mathrm{~nm})$ peaked further downwind than the reference particles (42.1-562 nm), and decayed significantly faster than larger particles particularly in the area 100-400 m downwind. Comparisons of the cumulative contributions of van der Waals enhanced coagulation, dry deposition, and dilution and the observed decay curves, imply that for up to the first 50-100 m there is nucleation and/or growth of particles smaller than $5.6 \mathrm{~nm}$. In contrast, in the 100-400 m region, some of the smaller particles evaporate, which would not apply for non-volatile ENMs but would be relevant for the interaction of ambient particles with ENMs. In the further downwind areas $(>400 \mathrm{~m})$ the particles all appear to decay at rates consistent with the sum of dilution, coagulation, and deposition. Keuken et al. $[160,161]$ performed measurements around Schiphol Airport (The Netherlands). Airplanes are strong emitters of UFP, compared to vehicles, producing more and smaller particles. Elevated UFP $(10-40 \mathrm{~nm})$ concentrations were detected at stations around Schiphol Airport, even up to $40 \mathrm{~km}$ distance, but with a shift in size from 10-20 nm close to Schiphol to 20-40 nm at $40 \mathrm{~km}$ distance. It should be noticed that field studies for UFP are particularly difficult to interpret since it is difficult to separate effects of change in size due to coagulation and removal of particles due to deposition, since both result in loss of total particle number. This implies that models are needed to interpret the results of field studies, whereas field studies are needed to constrain models.

\subsubsection{Dry Deposition}

Parameterizations for dry deposition of particles over a surface are often based on field experiments. Since these parameterizations work best for the conditions and species and circumstances for which they were derived they may not be accurate when extrapolating to other species and environments. Petroff and Zhang [162] show the deposition velocities from a compilation of 
observations for different surface types, with large scatter and hardly any observations for particles smaller than $100 \mathrm{~nm}$ for most surface types, so that it is difficult to validate their new parameterization. Their new parameterization has lower deposition velocities for the particles $<1 \mu \mathrm{m}$ than in the parameterization by Zhang et al. [163] that was and is still used in many chemistry-transport models, implying longer transport distances/lifetimes or higher relevance of wet deposition as removal mechanism. When such parameterizations are used in chemistry-transport models, additional uncertainties arise from the quantification of surface properties that are always a generalization in which regional and seasonal variations due to e.g., growing season, crop characteristics can easily induce variations in vegetation height of a factor 5 , which has an impact on the deposition velocity. New parameterizations are still being developed, addressing specific aspects of the process (e.g., for deposition on rough surface of simple shape by Zhang and Shao, [164]). Table 3 shows typical values calculated by and used in the LOTOS-EUROS model (using deposition scheme by [163]) for three representative land use types. Values exhibit a strong daily cycle and day-to-day variability, depending on weather conditions, and the values differ by an order of magnitude over the range of particle sizes.

Table 3. Typical deposition velocities in $\mathrm{m} / \mathrm{s}$ for the LOTOS-EUROS model [165].

\begin{tabular}{cccc}
\hline Particle Size & Desert & Grass & Forest \\
\hline $330 \mathrm{~nm}$ & $10^{-4}-1.5 \times 10^{-3}$ & $10^{-4}-2.5 \times 10^{-3}$ & $10^{-4}-5 \times 10^{-3}$ \\
$700 \mathrm{~nm}$ & $10^{-4}-10^{-3}$ & $10^{-4}-1.5 \times 10^{-3}$ & $10^{-4}-3 \times 10^{-3}$ \\
$3 \mu \mathrm{m}$ & $3 \times 10^{-4}-8 \times 10^{-4}$ & $3 \times 10^{-4}-1 \times 10^{-3}$ & $3 \times 10^{-4}-3 \times 10^{-3}$ \\
$5 \mu \mathrm{m}$ & $10^{-3}-2 \times 10^{-3}$ & $10^{-3}-1.5 \times 10^{-3}$ & $10^{-3}-0.013$ \\
$8 \mu \mathrm{m}$ & $2 \times 10^{-3}-7.5 \times 10^{-3}$ & $2 \times 10^{-3}-4 \times 10^{-3}$ & $2 \times 10^{-3}-0.065$ \\
\hline
\end{tabular}

\subsubsection{Wet Deposition}

Wet deposition can be separated into in-cloud processes and below-cloud processes, but often these processes are taken together as a bulk process for simplicity and the availability of observations (typically concentrations in rainwater). Andronache et al. [166] describe the role of several physical processes for scavenging of UFP in the boundary layer and combine the parameterization of several processes to come to an effective scavenging coefficient. Both below-cloud scavenging and in-cloud processing of UFP are important. Scavenging ratios are dependent on the particle size and composition on the one hand and cloud droplet/rain droplet size on the other. Below-cloud scavenging, entrainment in the cloud, in-cloud nucleation scavenging, in-cloud collection and coagulation scavenging are included in this effective scavenging coefficient. Observations above a boreal forest [167] show the largest scavenging coefficients for the smallest particles $\left(10 \mathrm{~nm}\right.$, order $\left.10^{-4} \mathrm{~s}^{-1}\right)$ with a minimum around $100 \mathrm{~nm}\left(10^{-5} \mathrm{~s}^{-1}\right)$, median values between $7 \times 10^{-6}$ and $4 \times 10^{-4} \mathrm{~s}^{-1}$. Andronache et al. [166] find values in the same range, based on theoretical considerations, but with the minimum scavenging coefficient around $50 \mathrm{~nm}$. The theoretical results indicate the largest sensitivity (differences $>$ factor 2) to the in-cloud collection efficiency for particles $>50 \mathrm{~nm}$, which is dependent on the solubility of the aerosol. Andronache et al. [166] state that for typical mixing during stratiform rain events, in-cloud processes dominate the UFP scavenging. Little is known about scavenging due to snowfall and the use of detailed microphysical models is required to study the interaction between particles and hydrometeors. Also diffusophoresis, thermophoresis and electric charging may play a role. Wet deposition is estimated to be of small importance for very small particles. For example, Andronache et al. [166] reported that particles need to grow to a diameter of $\sim 100 \mathrm{~nm}$ to become activated as cloud droplets. This means that ultrafine particles need to grow to this diameter. For nanoparticles in the nucleation mode size in range $(\sim 10 \mathrm{~nm})$ this would take a few days for typical growth rate of the particles of about $5 \mathrm{~nm} \mathrm{~h}^{-1}$ [24].

Wang et al. [168] have reviewed several theoretical and empirical size-resolved parameterizations of the wet scavenging coefficient, and compared them with available field and laboratory measurements. They investigated the uncertainties in several parameters and their impact (raindrop 
particle collection efficiency: 2 orders of magnitude in $0.01-3 \mu \mathrm{m}$ range, formulations of raindrop number size distribution: factor of 3 to 5 for all particle sizes, droplet terminal velocity: factor 2). Still, these uncertainties were not enough to overcome differences with observed values, and point at the importance of processes that were not included in these parameterizations (i.e., turbulent transport and mixing, cloud and aerosol microphysics) that influence field data but that are not considered in current theoretical parameterizations. For models that do not include explicit in-cloud processing, Wang et al. [168] recommend to use scavenging coefficients in the upper range of the values, but to be more conservative when in-cloud processing is included. This is in line with the findings of Andronache [166] who point at the importance of entrainment in clouds and cloud processing. According to Wang et al. [168], the net effect of the uncertainties is a factor 2-10 for the size-resolved particle concentrations and a factor 2 for the bulk mass and number concentrations. For snowfall additional research would be needed.

\subsection{Evaluation of Numerical Modelling in Assessing the Fate of UFP and ENMs}

For the determination of residence time and deposition of ENMs, it is difficult to rely on rules of thumb since large variations in time and space occur due to the intermittent character of clouds and rain and large differences in dry deposition velocities due to different surface roughness and atmospheric stability.

Still, to get an overall estimate of lifetime and concentrations in compartments (air, soil, and water), box or flow models can be used in which average conditions are assumed. Such a model was developed [169] and applied by e.g., Gottschalk et al. [29] using a probabilistic material flow. A different approach is to start from a materials flow model as used for the assessments of chemical substances for REACH as done by Meesters et al. [170]. In these models, all compartments are taken into account. For a broad overview of case studies we refer to Gottschalk et al. [171]. At the other side of the range, local models have been used. Computational Fluid Dynamics has been used to investigate behavior and concentrations of ultrafine particles close to the source [158]. Also Gaussian plume models, treating ultrafine particles as inert tracers [160,161] or including particle dynamics [172] have been used to make estimates close to the sources.

To arrive at spatial detailing for specific regions, chemistry-transport models can be used which explicitly resolve the timing of emissions, interaction with ambient particle concentrations, transport, cloud processes and deposition. Several models are available, all with different model formulations and parameterizations of the processes. Global models have been used with aerosol dynamics modules, mainly from the perspective of climate impact of aerosol. They resolve particle formation, emissions of natural (sea spray, desert dust) and anthropogenic aerosol (combustion, biomass burning) and quantify the impact of (ultrafine) particles on cloud formation and scattering and absorption of radiation. However, they cannot resolve high concentrations in source areas. Several parameterizations for aerosol dynamics were developed for these global models, both in sectional approaches and modal approaches. Both approaches have their advantages and disadvantages in terms of level of detail and computational effort. Examples are MAFOR [172], UHMA (Korhonen et al. [173]), M7 (Vignati et al. [174]), SALSA [175].

Such parameterizations have not only been applied in global, but in regional modelling as well. For regional-scale modelling over Europe, a special version of the model CAMx with a particle dynamics module (PMCAMX-UF) has been applied [176] with a new emission inventory for UFP. Also LOTOS-EUROS with the M7 [174] aerosol dynamics module has been applied [177] with an update of the emission inventory used by Fountoukis et al. [176]. Large-scale background concentrations were combined with Gaussian plume models to describe ultrafine particle concentrations originating from local traffic at city-level [177]. It should be noted that both, Fountoukis et al. [176] and Kukkonen et al. [177], found that although total particle number concentrations were represented reasonably well (within factor two) as compared with measurements, their size distribution showed too many small particles and too little large particles. This may be due to the use of the emission data, 
which may be representative for tailpipe conditions but not for conditions at short distance to the tailpipe. This cannot be resolved with a regional-scale model, although Fountoukis et al. [176] used a preprocessor for the emission to compensate for this. Other reasons for the observed discrepancy might be a lack of interaction with semi-volatile organic particles [178,179], interaction with other secondary aerosols (e.g., ammonium nitrate), and large uncertainties in the parameterization of nucleation that may be region-specific but is applied over larger areas. Whilst the uncertainties in nucleation are assumed to be less relevant for the ENM fate modelling, taking account of condensables and near-source processes is important for regional-scale models. The existing models should be extended with new tracers to take ENMs into account. Special attention should be paid to surface properties of ENM, that may influence their behavior regarding condensation of species, water uptake, coagulation efficiencies, and behavior in clouds with electric charges.

Despite all uncertainties, a simple estimate of the lifetime and transport distances of particles can be carried out, based on explicit calculations with the LOTOS-EUROS model. This model has been used to trace emissions of a passive tracer with assumed particle diameter of $700 \mathrm{~nm}$ [180] (model characteristics identical to elemental carbon), released at constant emission rate of $10 \mathrm{~kg} / \mathrm{h}$ at a point source in the Netherlands. Concentrations and depositions were calculated for the year 2012, and annual average concentration and annual total deposition are displayed in Figure 2.

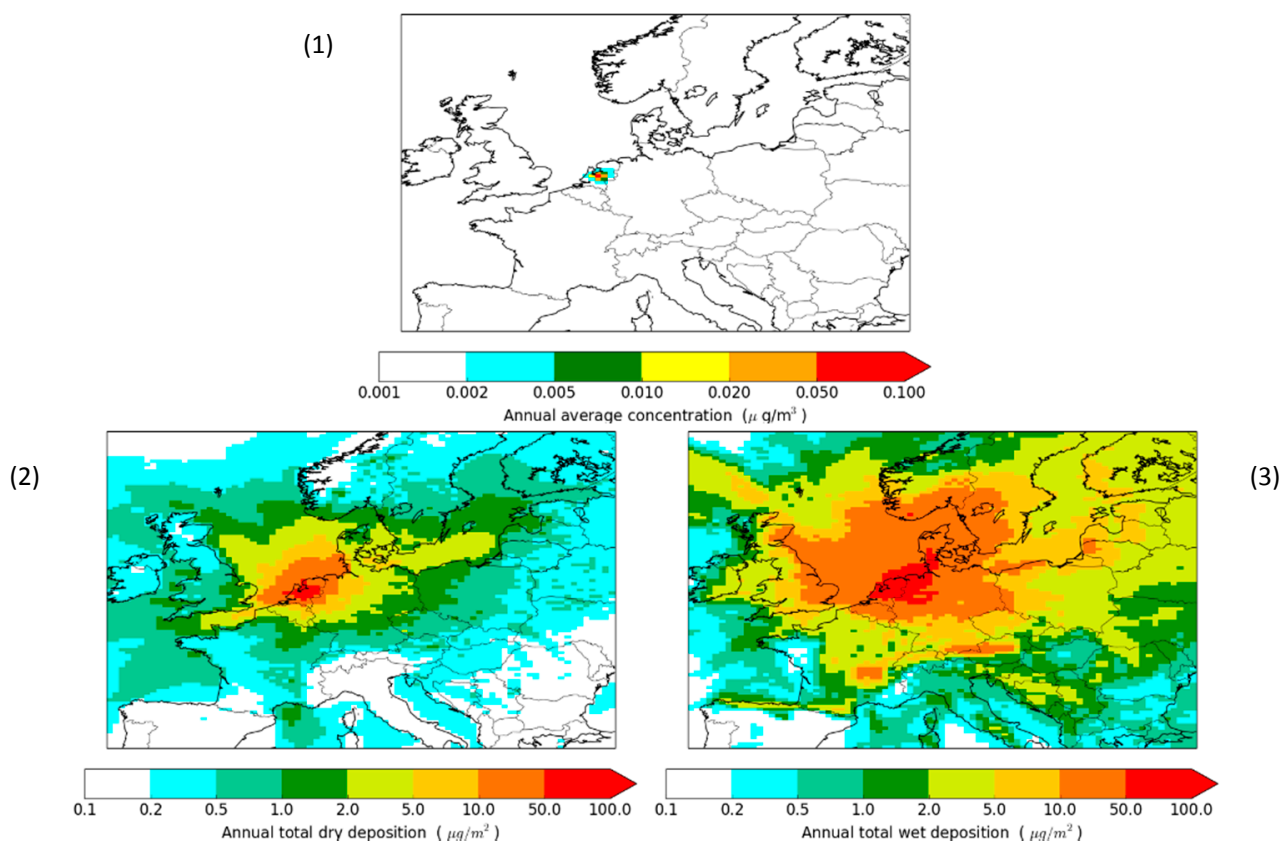

Figure 2. Annual average concentration (1) and total dry (2) and wet (3) deposition for a passive tracer released from a point source in The Netherlands with emission rate of $10 \mathrm{~kg} / \mathrm{h}$. Results from model simulation with LOTOS-EUROS for 2012.

Elevated concentrations were found up to distances of the order of $50 \mathrm{~km}$ in the annual average, but absolute transport distances are larger. Deposition maps show that nearly the whole model domain receives some of the tracer, albeit in small quantities. In particular, remote mountain areas receive significant amounts of the tracer due to larger amounts of rain related to orography. This example should be considered as a very rough indication of the order of magnitude study, since aerosol dynamics were not taken into account, the diameter that was taken is certainly not representative for all types of ENMs, and uncertainties in wet and dry deposition velocity are easily a factor 2. However, these results indicate that for modelling the fate of ENMs, a reasonable modelling domain should cover at least a circle of $100 \mathrm{~km}$ around the source to describe concentrations in air. When looking at the overall fate of ENM, including deposition to soil and water, the scale of a large river catchment 
(e.g., the Rhine) would be an appropriate scale. It should be noted that for the atmosphere, removal is relatively efficient and a simulation of one year would be fairly representative. For soil and water, processes are slower so that the spatial scale would match but longer periods must be modelled to come to representative concentrations in soil and water.

\section{Conclusions}

Although only a small portion of ENMs is assumed to be released into ambient air compared to the other compartments, increasing use of ENMs might result in atmospheric concentrations relevant for climate, health and water, soil or biota after ENM transformation in the atmosphere. Therefore, their implications on the atmosphere have to be investigated, as well as transformations occurring in the atmospheric reactor and thus influencing ENM environmental fate.

Regarding the release of ENM, data are very scarce as measurements around production plants have not been conducted or published. Field measurements concerning the release during the life cycle are extremely important, but even more challenging due to the still small amounts of airborne ENMs and the need to differentiate between ENMs and other natural or anthropogenic (ultrafine) particles. Hence no real values of ENM emission could be given for all discussed processes (Section 2). At least some information is available from the end-of-life waste treatment.

Regarding the transformation of ENMs in the atmosphere, relevant reactions can be deduced from theoretical considerations regarding physical and chemical processes. Few experimental studies have either confirmed these assumptions or have shown new insights into the special behavior of ENMs. However, the major part of data needed to assess environmental fate of ENMs actually has to be derived from information available for UFP. These can often be used as a proxy, especially for situations when ENMs and UFP are intimately mixed together. However, differences can result e.g., from differing ENM surface properties, distinct shapes and diverging chemical composition. Problems in obtaining specific data arise inter alia due to the vast majority of different ENMs available already or in the near future, meaning that experiments are unmanageable to cover all possible reactions. Therefore, approaches are needed to compile relevant groups of ENMs for similar atmospheric implications. These groups not only need to cover pristine ENMs with and without coating, but also environmentally processed ones.

In order to reveal the fate of airborne ENMs, lab and field studies have to be complemented by regional to global modelling, for specific cases like accidental release of ENMs also by near-field local modelling.

As a first conclusion from UFP modelling, it is clear that they have residence times from minutes to several days and can be transported over substantial distances. However, more specific cases must be defined to determine the overall fate of ENMs since characteristics may vary widely from case to case, e.g., motor oil additive versus $\mathrm{TiO}_{2}$ spraying. Another aspect is the possible difference when the same type of ENM is released during production, the use phase or at the end of life. While during the latter two, in most cases no pristine ENM will be released, this is more likely during production. Due to this we will have to deal with two different starting points for the further consideration of the ENM environmental behavior. Furthermore, transport distances for an accidental release of high ENM concentrations to protect people from exposure is a very different question than estimating transport distances for the load of ENM originating from diffuse sources received by remote ecosystems. In the first case dilution is the most important factor, in the second case deposition and rainout are more important and change of surface properties must also be taken into account.

More research is needed on in-cloud processes, which can be an important sink and determine where particles are deposited. For the fate of ENMs in terms of particle dynamics and cloud processing, clear information on their surface properties is needed to describe their interaction with ambient aerosol or cloud water, since it not only affects their atmospheric lifetime but also their availability for uptake by biota, attachment to soil and solubility in water bodies. 
From the investigations carried out so far, it can be deduced that although being very interesting scientifically, the effect of ENMs on the atmosphere is not seen as an urgent research need due to their actually low concentrations and therefore lower impact compared to conventional (ultrafine) particles. On the other hand, different open questions regarding the fate of airborne ENMs in the environment have to be addressed. Prioritization of these research needs is a difficult task due to the multitude of materials, the large range of production amounts for different ENMs and the variety of release scenarios.

A major research focus regarding environmental transport should be the form of release. For ENMs that are attached to other particles or embedded in a matrix, the uncertainties are no different than for conventional particles and no nano-specific uncertainties apply. In contrast, for ENMs that are released as free particles the uncertainties are largest in all aspects, as they are most difficult to measure and deposition and coagulation are both important and difficult to separate in experiments. A second key aspect is research on the transformation of (pristine) ENMs alternating their environmental properties, information which is urgently needed for modelling. It is understood that investigations will first concentrate on the materials being (environmentally) toxic and/or being produced in large amounts.

Acknowledgments: This review was prepared within the NanoFASE project that received funding from the European Union's Horizon 2020 research and innovation program under grant agreement No 646002 which also covered the costs to publish in open access.

Author Contributions: Astrid John was the main author and worked on the overall manuscript, Miriam Küpper contributed to the chapters on transformation and atmospheric implications. Astrid Manders-Groot is responsible for the chapter on modelling and atmospheric lifetime. Bruno Debray and Jean-Marc Lacome are responsible for the chapter on ENM release during their lifecycle and the section on accidental modelling. Thomas Kuhlbusch triggered this review and gave valuable input to the manuscript.

Conflicts of Interest: The authors declare no conflict of interest.

\section{Abbreviations}

The following abbreviations are used in this manuscript:

$\begin{array}{ll}\text { CNT } & \text { Carbon nano-tubes } \\ \text { ENM } & \text { Engineered Nanomaterial(s) } \\ \text { NP } & \text { Nanoparticle(s) } \\ \text { ROS } & \text { Reactive oxygen species } \\ \text { UFP } & \text { Ultrafine particles }\end{array}$

\section{References}

1. Commission Recommendation of 18 October 2011 on the Definition of Nanomaterial (2011/696/EU). Available online: https://ec.europa.eu/research/industrial_technologies/pdf/policy/commissionrecommendation-on-the-definition-of-nanomater-18102011_en.pdf (accessed on 2 May 2017).

2. Products of Nanotechnologies Adopted by the SCENIHR during the 28th Plenary Meeting of 19 January 2009. Available online: http://ec.europa.eu/health/archive/ph_risk/committees/04_scenihr/docs/scenihr_o_ 023.pdf (accessed on 14 June 2016).

3. Kreyling, W.G.; Semmler-Behnke, M.; Chaudhry, Q. A complementary definition of nanomaterial. Nano Today 2010, 5, 165-168. [CrossRef]

4. Auffan, M.; Rose, J.; Bottero, J.Y.; Lowry, G.V.; Jolivet, J.P.; Wiesner, M.R. Towards a definition of inorganic nanoparticles from an environmental, health and safety perspective. Nat. Nanotechnol. 2009, 4, 634-641. [CrossRef] [PubMed]

5. Borm, P.J.; Robbins, D.; Haubold, S.; Kuhlbusch, T.; Fissan, H.; Donaldson, K.; Schins, R.; Stone, V.; Kreyling, W.; Lademann, J.; et al. The potential risks of nanomaterials: A review carried out for ECETOC. Part. Fibre Toxicol. 2006, 3, 1. [CrossRef] [PubMed]

6. Wu, J.; Pei, L.; Xuan, S.; Yan, Q.; Gong, X. Particle size dependent rheological property in magnetic fluid. J. Magn. Magn. Mater. 2016, 408, 18-25. [CrossRef] 
7. Gupta, A.; Wiggers, H. Freestanding silicon quantum dots: Origin of red and blue luminescence. Nanotechnology 2010, 22, 055707. [CrossRef] [PubMed]

8. Manke, A.; Wang, L.; Rojanasakul, Y. Mechanisms of nanoparticle-induced oxidative stress and toxicity. BioMed Res. Int. 2013. [CrossRef] [PubMed]

9. Garner, K.L.; Keller, A.A. Emerging patterns for engineered nanomaterials in the environment: A review of fate and toxicity studies. J. Nanopart. Res. 2014, 16, 1-28. [CrossRef]

10. Sajid, M.; Ilyas, M.; Basheer, C.; Tariq, M.; Daud, M.; Baig, N.; Shehzad, F. Impact of nanoparticles on human and environment: Review of toxicity factors, exposures, control strategies, and future prospects. Environ. Sci. Pollut. Res. Int. 2015, 22, 4122-4143. [CrossRef] [PubMed]

11. Farré, M.; Sanchís, J.; Barceló, D. Analysis and assessment of the occurrence, the fate and the behavior of nanomaterials in the environment. Trends Anal. Chem. 2011, 30, 517-527. [CrossRef]

12. French Ministry for Ecology, Energy and Sea. Éléments Issus des Déclarations des Substances à l'État Nanoparticulaire. Direction Générale de la Prévention des Risques, Service des Risques Sanitaires Liés à l’Environnement, des Déchets et des Pollutions Diffuses, December 2015. Available online: https:/ /www. actu-environnement.com/media/pdf/news-27025-rapport-r-nano.pdf (accessed on 2 May 2017).

13. Sun, T.Y.; Gottschalk, F.; Hungerbühler, K.; Nowack, B. Comprehensive probabilistic modelling of environmental emissions of engineered nanomaterials. Environ. Pollut. 2014, 185, 69-76. [CrossRef] [PubMed]

14. Research and Markets. Available online: http://www.researchandmarkets.com/reports/2488811/the global_market_for_metal_oxide_nanoparticles (accessed on 3 November 2016).

15. Nowack, B.; Brouwer, C.; Geertsma, R.E.; Heugens, E.H.W.; Ross, B.L.; Toufektsian, M.C.; Wijnhoven, S.W.P.; Aitken, R.J. Analysis of the occupational, consumer and environmental exposure to engineered nanomaterials used in 10 technology sectors. Nanotoxicology 2012, 7, 1152-1156. [CrossRef] [PubMed]

16. Collin, B.; Auffan, M.; Johnson, A.C.; Kaur, I.; Keller, A.A.; Lazareva, A.; Lead, J.R.; Ma, X.; Merrifield, R.C.; Svendsen, C.; et al. Environmental release, fate and ecotoxicological effects of manufactured ceria nanomaterials. Environ. Sci. Nano 2014, 1, 533-548. [CrossRef]

17. Xia, T.; Li, N.; Nel, A.E. Potential health impact of nanoparticles. Annu. Rev. Public Health 2009, 30, 137-150. [CrossRef] [PubMed]

18. Montaño, M.D.; Lowry, G.V.; von der Kammer, F.; Blue, J.; Ranville, J.F. Current status and future direction for examining engineered nanoparticles in natural systems. Environ. Chem. 2014, 11, 351-366. [CrossRef]

19. Kuhlbusch, T.A.; Quincey, P.; Fuller, G.W.; Kelly, F.; Mudway, I.; Viana, M.; Querol, X.; Alastuey, A.; Katsouyanni, K.; Weijers, E.; et al. New Directions: The future of European urban air quality monitoring. Atmos. Environ. 2014, 87, 258-260. [CrossRef]

20. Abbott, L.C.; Maynard, A.D. Exposure assessment approaches for engineered nanomaterials. Risk Anal. 2010, 30, 1634-1644. [CrossRef] [PubMed]

21. Meesters, J.A.; Veltman, K.; Hendriks, A.J.; van de Meent, D. Environmental exposure assessment of engineered nanoparticles: Why REACH needs adjustment. Integr. Environ. Assess. Manag. 2013, 9, e15-e26. [CrossRef] [PubMed]

22. Nowack, B.; Ranville, J.F.; Diamond, S.; Gallego-Urrea, J.A.; Metcalfe, C.; Rose, J.; Horne, N.; Koelmans, A.A.; Klaine, S.J. Potential scenarios for nanomaterial release and subsequent alteration in the environment. Environ. Toxicol. Chem. 2012, 31, 50-59. [CrossRef] [PubMed]

23. Matsumoto, K.; Tanaka, H. Formation and dissociation of atmospheric particulate nitrate and chloride: An approach based on phase equilibrium. Atmos. Environ. 1996, 30, 639-648. [CrossRef]

24. Kulmala, M.; Vehkamäki, H.; Petäjä, T.; Dal Maso, M.; Lauri, A.; Kerminen, V.M.; Birmly, W.; McMurry, P.H. Formation and growth rates of ultrafine atmospheric particles: A review of observations. J. Aerosol Sci. 2004, 35, 143-176. [CrossRef]

25. Khoder, M.I. Atmospheric conversion of sulfur dioxide to particulate sulfate and nitrogen dioxide to particulate nitrate and gaseous nitric acid in an urban area. Chemosphere 2002, 49, 675-684. [CrossRef]

26. Gutleb, A.C.; Cambier, S.; Fernandes, T.; Georgantzopoulou, A.; Kuhlbusch, T.A.J.; Lynch, I.; Macken, A.; Mehennaoui, K.; Mowller, R.; Nickel, C.; et al. Chapter 4: Environmental Fate and Effects of Nanomaterials in Aquatic Freshwater Environments. In Nanomaterials-A Guide to Fabrication and Applications; Krishnamoorthy, S., Ed.; CRC Press: Boca Raton, FL, USA, 2015. 
27. Baalousha, M.; Cornelis, G.; Kuhlbusch, T.A.J.; Lynch, I.; Nickel, C.; Peijnenburg, W.; van den Brink, N.W. Modeling nanomaterial fate and uptake in the environment: Current knowledge and future trends. Environ. Sci. Nano 2016, 3, 323. [CrossRef]

28. Keller, A.; McFerran, S.; Lazareva, A.; Suh, S. Global life cycle releases of engineered nanomaterials. J. Nanopart. Res. 2013, 15, 1-17. [CrossRef]

29. Gottschalk, F.; Lassen, C.; Kjoelholt, J.; Christensen, F.; Nowack, B. Modeling flows and concentrations of nine engineered nanomaterials in the Danish environment. Int. J. Environ. Res. Public Health 2015, 12, 5581-5602. [CrossRef] [PubMed]

30. Mueller, N.C.; Nowack, B. Exposure modeling of engineered nanoparticles in the environment. Environ. Sci. Technol. 2008, 42, 4447-4453. [CrossRef] [PubMed]

31. Mahendra, S.; Zhu, H.; Colvin, V.L.; Alvarez, P.J. Quantum dot weathering results in microbial toxicity. Environ. Sci. Technol. 2008, 42, 9424-9430. [CrossRef] [PubMed]

32. Fabrega, J.; Fawcett, S.R.; Renshaw, J.C.; Lead, J.R. Silver nanoparticle impact on bacterial growth: Effect of pH, concentration, and organic matter. Environ. Sci. Technol. 2009, 43, 7285-7290. [CrossRef] [PubMed]

33. Li, D.; Lyon, D.Y.; Li, Q.; Alvarez, P.J. Effect of soil sorption and aquatic natural organic matter on the antibacterial activity of a fullerene water suspension. Environ. Toxicol. Chem. 2008, 27, 1888-1894. [CrossRef] [PubMed]

34. Tong, Z.; Bischoff, M.; Nies, L.; Applegate, B.; Turco, R.F. Impact of fullerene (C60) on a soil microbial community. Environ. Sci. Technol. 2007, 41, 2985-2991. [CrossRef] [PubMed]

35. Owen, R.; Handy, R. Viewpoint: Formulating the problems for environmental risk assessment of nanomaterials. Environ. Sci. Technol. 2007, 41, 5582-5588. [PubMed]

36. Wiesner, M.R.; Lowry, G.V.; Jones, K.L.; Hochella, M.F., Jr.; Di Giulio, R.T.; Casman, E.; Bernhardt, E.S. Decreasing Uncertainties in assessing environmental exposure, risk, and ecological implications of nanomaterials. Environ. Sci. Technol. 2009, 43, 6458-6462. [CrossRef] [PubMed]

37. Tiwari, A.J.; Marr, L.C. The Role of Atmospheric Transformations in Determining Environmental Impacts on Carbonaceous Nanoparticles. J. Environ. Qual. 2010, 39, 1883-1895. [CrossRef] [PubMed]

38. Bernhardt, E.S.; Colman, B.P.; Hochella, M.F.; Cardinale, B.J.; Nisbet, R.M.; Richardson, C.J.; Yin, L. An ecological perspective on nanomaterial impacts in the environment. J. Environ. Qual. 2010, 39, 1954-1965. [CrossRef] [PubMed]

39. Lowry, G.V.; Gregory, K.B.; Apte, S.C.; Lead, J.R. Transformations of nanomaterials in the environment. Environ. Sci. Technol. 2012, 46, 6893-6899. [CrossRef] [PubMed]

40. Ding, Y.; Kuhlbusch, T.; Tongeren, M.; Jiménez, A.S.; Tuinman, I.; Chen, R.; Larazza Alvaraz, I.; Mikolajczik, U.; Nickel, C.; Meyer, J.; et al. Airborne engineered nanomaterials in the workplace-A review of release and worker exposure during nanomaterial production and handling processes. J. Hazard. Mater. 2016, 322 Pt A, 17-28. [CrossRef] [PubMed]

41. Kuhlbusch, T.; Asbach, C.; Fissan, H.; Göhler, D.; Stintz, M. Nanoparticle exposure at nanotechnology workplaces: A review. Part. Fibre Toxicol. 2011, 8. [CrossRef] [PubMed]

42. Brouwer, D. Exposure to manufactured nanoparticles in different workplaces. Toxicology 2010, 269, $120-127$. [CrossRef] [PubMed]

43. Caballero-Guzman, A.; Nowack, B. A critical review of engineered nanomaterial release data: Are current data useful for material flow modeling? Environ. Pollut. 2016, 213, 502-517. [CrossRef] [PubMed]

44. Nanoengineering - Global Approaches to Health and Safety Issues; Dolez, P.I. (Ed.) Elsevier: Amsterdam, The Netherlands, 2015.

45. Nowack, B.; Mueller, N.C.; Krug, H.F.; Wick, P. How to consider engineered nanomaterials in major accident regulations? Environ. Sci. Eur. 2014, 26, 1-10. [CrossRef]

46. Gottschalk, F.; Nowack, B. The release of engineered nanomaterials to the environment. J. Environ. Monit. 2011, 13, 1145-1155. [CrossRef] [PubMed]

47. Broomfield, M.; Foss Hansen, S.; Pelsy, F. Support for 3rd Regulatory Review on Nanomaterials: Project Report; European Commission; ENV.A.3/ETU/2015/0030; Publications Office of the European Union: Luxembourg, 2016.

48. XP CEN ISO/TS 80004-8:2013. Nanotechnologies-Vocabulary-Part 8: Nanomanufacturing Processes. Classification Index: T 16-101-8. AFNOR: Paris, June 2015. Available online: https:/ / www.iso.org/standard/ 52937.html (accessed on 2 May 2017). 
49. Vignes, A. Panorama des Principaux Procédés de Production, Utilisation, Transformation de Nanomatériaux; Rapport DRA-14-133557-00736A; INERIS: Verneuil-en-Halatte, France, 2013; 82 p.

50. Virji, M.A.; Stefaniak, A.B. A Review of Engineered Nanomaterial Manufacturing Processes and Associated Exposures, Comprehesive Materials Processing; Elsevier: Amsterdam, The Netherlands, 2014; Volume 8, pp. 103-125.

51. Geraci, C.; Heidel, D.; Sayes, C.; Hodson, L.; Schulte, P.; Eastlake, A.; Brenner, S. Perspectives on the design of safer nanomaterials and manufacturing processes. J. Nanopart. Res. 2015, 17, 366. [CrossRef] [PubMed]

52. Gridelet, L.; Delbecq, P.; Hervé, L.; Boissolle, P.; Fleury, D.; Kowal, S.; Fayet, G. Proposal of a new risk assessment method for the handling of powders and nanomaterials. Ind. Health 2015, 53, 56-68. [CrossRef] [PubMed]

53. Report for EU Project MARINA: Managing Risks of Nanomaterials; Summary Report on Processes and Activities Related to NM Lifecycle within Small and Large Industries; Grant Agreement Number 263215. Available online: http://www.marina-fp7.eu/activities/exposure/MARINA_Processes_Activities_related_ NM_Lifecycle.pdf (accessed on 2 May 2017).

54. Engineered Nanomaterials: Evidence on the Effectiveness of Workplace Controls to Prevent Exposure. Safe Work Australia; 978-0-642-32884-72009; 75 p. Available online: https://www.safeworkaustralia.gov.au/system/files/documents/1702/engineerednanomaterials_ evidence_effectiveness_workplacecontrolstopreventexposure_2009_pdf.pdf (accessed on 2 May 2017).

55. NF EN 1822-1:2010, High Efficiency Air Filters (EPA, HEPA and ULPA)-Part 1: Classification, Performance Testing, Marking, Classification Index: X 44-014-1, AFNOR, Paris, January 2010. Available online: https: / www.boutique.afnor.org/norme/nf-en-1822-1/filtres-a-air-a-haute-efficacite-epa-hepaet-ulpa-partie-1-classification-essais-de-performance-et-marquage/article/774500/fa157753 (accessed on 2 May 2017).

56. Lee, K.W.; Liu, B.Y.H. On the Minimum Efficiency and the Most Penetrating Particle Size for Fibrous Filters. J. Air Pollut. Control. Assoc. 1980, 30, 377-381. [CrossRef]

57. Podgórski, A.; Bałazy, A.; Gradon, L. Application of nanofibers to improve the filtration efficiency of the most penetrating aerosol particles in fibrous filters. Chem. Eng. Sci. 2006, 61, 6804-6815. [CrossRef]

58. Jones, A.M.; Harrison, R.M. Emission of ultrafine particles from the incineration of municipal solid waste: A review. Atmos. Environ. 2016, 140, 519-528. [CrossRef]

59. Hleis, D.; Fernández-Olmo, I.; Ledoux, F.; Kfoury, A.; Courcot, L.; Desmonts, T.; Courcot, D. Chemical profile identification of fugitive and confined particle emissions from an integrated iron and steelmaking plant. J. Hazard. Mater. 2013, 250-251, 246-255. [CrossRef] [PubMed]

60. Monfort, E.; Sanfélix, V.; Celades, I.; Gomar, S.; Martín, F.; Aceña, B.; Pascual, A. Diffuse PM 10 emission factors associated with dust abatement technologies in the ceramic industry. Atmos. Environ. 2011, 45, 7286-7292. [CrossRef]

61. Nowack, B.; David, R.M.; Fissan, H.; Morris, H.; Shatkin, J.A.; Stintz, M.; Zepp, R.; Brouwer, D. Potential release scenarios for carbon nanotubes used in composites. Environ. Int. 2013, 59, 1-11. [CrossRef] [PubMed]

62. Directive 2010/75/Eu of the European Parliament and of the Council of 24 November 2010; on Industrial Emissions (Integrated Pollution Prevention and Control). Official Journal of the European Union, 17 December 2010; p. L: 334/17. Available online: http://eur-lex.europa.eu/LexUriServ/LexUriServ. do?uri=OJ:L:2010:334:0017:0119:en:PDF (accessed on 4 May 2017).

63. European Pollutant Release and Transfer Register. Available online: http://prtr.ec.europa.eu/ (accessed on 2 May 2017).

64. Décret no 2012-232 du 17 Février 2012 Relatif à la Déclaration Annuelle des Substances à l’Etat Nanoparticulaire Pris en Application de l'Article, L., 523-4 du Code de l'Environnement. Journal Officiel de la République Française, 19 February 2012. Available online: https:/ / www.legifrance.gouv.fr/affichTexte. do?cidTexte=JORFTEXT000025377246\&categorieLien=id (accessed on 4 May 2017).

65. R-Nano, Eléments Issus des Déclarations des Substances à L'état Nanoparticulaire, Déclarations des Substances à l'État Nanoparticulaire-Exercice 2015: Rapport D'étude. Ministère de l'Environnement, de l'Énergie et de la Mer: Paris, France, 2015. Available online: https://www.r-nano.fr (accessed on 2 May 2017). 
66. Bressot, C.; Manier, N.; Pagnoux, C.; Aguerre-Chariol, O.; Morgeneyer, M. Environmental release of engineered nanomaterials from commercial tiles under standardized abrasion conditions. J. Hazard. Mater. 2017, 322 Pt A, 276-283. [CrossRef] [PubMed]

67. Wohlleben, W.; Brill, S.; Meier, M.W.; Mertler, M.; Cox, G.; Hirth, S.; von Vacano, B.; Strauss, V.; Treumann, S.; Wiench, K.; et al. On the Lifecycle of Nanocomposites: Comparing Released Fragments and their In-Vivo Hazards from Three Release Mechanisms and Four Nanocomposites. Small 2011, 7, 2384-2395. [CrossRef] [PubMed]

68. Reijnders, L. The release of $\mathrm{TiO}_{2}$ and $\mathrm{SiO}_{2}$ nanoparticles from nanocomposites. Polym. Degrad Stab. 2009, 94, 873-876. [CrossRef]

69. Göhler, D.; Stintz, M.; Hillemann, L.; Vorbau, M. Characterization of Nanoparticle Release from Surface Coatings by the Simulation of a Sanding Process. Ann. Occup. Hyg. 2010, 54, 615-624. [CrossRef] [PubMed]

70. Le Bihan, O.; Shandilya, N.; Gheerardyn, L.; Guillon, O.; Dore, E.; Morgeneyer, M. Investigation of the release of particles from a nanocoated product. Adv. Nanopart. 2013, 2, 39-44. [CrossRef]

71. Kuhlbusch, T.; Kaminski, H. Release from Composites by Mechanical and Thermal Treatment: Test Methods. In Safety of Nanomaterials along Their Life Cycle; Wohleben, W., Kuhlbusch, T., Schnekenburger, J., Lehr, C.-M., Eds.; CRC Press: New York, NY, USA, 2015; pp. 247-276.

72. Froggett, S.J.; Clancy, S.F.; Boverhof, D.R.; Canady, R.A. A review and perspective of existing research on the release of nanomaterials from solid nanocomposites. Part. Fibre Toxicol. 2014, 11, 17. [CrossRef] [PubMed]

73. Wohlleben, W.; Kuhlbusch, T.A.; Schnekenburger, J.; Lehr, C.M. Safety of Nanomaterials along Their Lifecycle: Release, Exposure, and Human Hazards; CRC Press: New York, NY, USA, 2015.

74. Holder, A.L.; Vejerano, E.P.; Zhoub, X.; Marr, L.C. Nanomaterial disposal by incineration. Environ. Sci. Process. Impacts 2013, 15, 1652-1664. [CrossRef] [PubMed]

75. Ounoughene, G.; Le Bihan, O.; Chivas-Joly, C.; Motzkus, C.; Longuet, C.; Debray, B.; Joubert, A.; Le Coq, L.; Lopez-Cuesta, J.M. Behavior and fate of halloysite nanotubes (HNTs) when incinerating PA6/HNTs nanocomposite. Environ. Sci. Technol. 2015, 49, 5450-5457. [CrossRef] [PubMed]

76. Ounoughene, G.; Le Bihan, O.; Chivas-Joly, C.; Longuet, C.; Motzkus, C.; Debray, B.; Joubert, A.; Lopez-Cuesta, J.M.; Le Coq, L. Aerosol of silica nanoparticles generated during the combustion of a polysiloxane nanocomposite. In Proceedings of the Aerosol Technology 2015 conference, Tampere, Finland, 15-17 June 2015; Available online: http:/ / www.tut.fi/at2015/wp-content/uploads/abstracts_download.pdf (accessed on 2 May 2017).

77. Kiser, M.A.; Westerhoff, P.; Benn, T.; Wang, Y.; Pérez-Rivera, J.; Hristovski, K. Titanium nanomaterial removal and release from wastewater treatment plants. Environ. Sci. Technol. 2009, 43, 6757-6763. [CrossRef] [PubMed]

78. Limbach, L.K.; Bereiter, R.; Müller, E.; Krebs, R.; Gälli, R.; Stark, W.J. Removal of Oxide Nanoparticles in a Model Wastewater Treatment Plant: Influence of Agglomeration and Surfactants on Clearing Efficiency. Environ. Sci. Technol. 2008, 42, 5828-5833. [CrossRef] [PubMed]

79. Kumar, P.; Fennell, P.; Robins, A. Comparison of the behaviour of manufactured and other airborne nanoparticles and the consequences for prioritising research and regulation activities. J. Nanopart. Res. 2010, 12, 1523-1530. [CrossRef] [PubMed]

80. Hristozov, D.; Malsch, I. Hazards and Risks of Engineered Nanoparticles for the Environment and Human Health. Sustainability 2009, 1, 1161-1194. [CrossRef]

81. Hinds, W.C. Aerosol Technology: Properties, Behavior, and Measurement of Airborne Particles, 2nd ed.; John Wiley \& Sons Inc.: New York, NY, USA, 1999; 504 p.

82. Maynard, A.D.; Kuempel, E.D. Airborne nanostructured particles and occupational health. J. Nanopart. Res. 2005, 7, 587-614. [CrossRef]

83. Quik, J.T.K.; Stuart, M.C.; Wouterse, M.; Peijnenburg, W.; Hendriks, A.J.; van de Meent, D. Natural colloids are the dominant factor in the sedimentation of nanoparticles. Environ. Toxicol. Chem. 2012, 31, 1019-1022. [CrossRef] [PubMed]

84. Kulkarni, P.; Baron, P.A.; Willeke, K. Aerosol Measurement: Principles, Techniques, and Applications; John Wiley \& Sons: Hoboken, NJ, USA, 2011.

85. Seipenbusch, M.; Binder, A.; Kasper, G. Temporal Evolution of Nanoparticle Aerosols in Workplace Exposure. Ann. Occup. Hyg. 2008, 52, 707-716. [PubMed] 
86. Diegoli, S.; Manciulea, A.L.; Begum, S.; Jones, I.P.; Lead, J.R.; Preece, J.A. Interaction between manufactured gold nanoparticles and naturally occurring organic macromolecules. Sci. Total Environ. 2008, 402, 51-61. [CrossRef] [PubMed]

87. Stankus, D.P.; Lohse, S.E.; Hutchison, J.E.; Nason, J.A. Interactions between natural organic matter and gold nanoparticles stabilized with different organic capping agents. Environ. Sci. Technol. 2010, 45, 3238-3244. [CrossRef] [PubMed]

88. Graber, E.R.; Rudich, Y. Atmospheric HULIS: How humic-like are they? A comprehensive and critical review. Atmos. Chem. Phys. 2006, 6, 729-753. [CrossRef]

89. Lee, J.; Donahue, N.M. Secondary Organic Aerosol Coating of Synthetic Metal-Oxide Nanoparticles. Environ. Sci. Technol. 2011, 45, 4689-4695. [CrossRef] [PubMed]

90. Kupc, A.; Bischof, O.; Tritscher, T.; Beeston, M.; Krinke, T.; Wagner, P.E. Laboratory characterization of a new nano-water-based CPC 3788 and performance comparison to an ultrafine butanol-based CPC 3776. Aerosol Sci. Technol. 2013, 47, 183-191. [CrossRef]

91. Asbach, C.; Meyer-Plath, A.; Clavaguera, S.; Fierz, M.; Dahmann, D.; MacCalman, L.; Alexander, C.; Todea, A.M.; Iavicoli, I. nanoIndEx-Assessment of Personal Exposure to Airborne Nanomaterials-A Guidance Document. 2016, p. 47. Available online: http://www.nanoindex.eu/wp-content/uploads/2016/ 06/Nano_Brosch\%C3\%BCre.pdf (accessed on 4 October 2016).

92. Slowik, J.G.; Cross, E.S.; Han, J.H.; Kolucki, J.; Davidovits, P.; Williams, L.R.; Onasch, T.B.; Jayne, J.T.; Kolb, C.E.; Worsnop, D.R. Measurements of morphology changes of fractal soot particles using coating and denuding experiments: Implications for optical absorption and atmospheric lifetime. Aerosol Sci. Technol. 2007, 41, 734-750. [CrossRef]

93. Weingartner, E.; Burtscher, H.; Baltensperger, U. Hygroscopic properties of carbon and diesel soot particles. Atmos. Environ. 1997, 31, 2311-2327. [CrossRef]

94. Borm, P.; Klaessig, F.C.; Landry, T.D.; Moudgil, B.; Pauluhn, J.; Thomas, K.; Trottier, R.; Wood, S. Research strategies for safety evaluation of nanomaterials, part V: Role of dissolution in biological fate and effects of nanoscale particles. Toxicol. Sci. 2006, 90, 23-32. [CrossRef] [PubMed]

95. Pruppacher, H.R.; Jaenicke, R. The processing of water vapor and aerosols by atmospheric clouds, a global estimate. Atmos. Res. 1995, 38, 283-295. [CrossRef]

96. Desboeufs, K.V.; Losno, R.; Colin, J.L. Factors influencing aerosol solubility during cloud processes. Atmos. Environ. 2001, 35, 3529-3537. [CrossRef]

97. Spokes, L.J.; Jickells, T.D.; Lim, B. Solubilisation of aerosol trace metals by cloud processing: A laboratory study. Geochim. Cosmochim. Acta 1994, 58, 3281-3287. [CrossRef]

98. Kaptay, G. On the size and shape dependence of the solubility of nano-particles in solutions. Int. J. Pharm. 2012, 430, 253-257. [CrossRef] [PubMed]

99. Mihranyana, A.; Strømme, M. Solubility of fractal nanoparticles. Surf. Sci. 2007, 601, 315-319. [CrossRef]

100. Quadros, M.E.; Marr, L.C. Environmental and Human Health Risks of Aerosolized Silver Nanoparticles. J. Air Waste Manag. Assoc. 2010, 60, 770-781. [CrossRef] [PubMed]

101. McMahon, M.D.; Lopez, R.; Meyer, H.M., III; Feldman, L.C.; Haglund, R.F., Jr. Rapid tarnishing of silver nanoparticles in ambient laboratory air. Appl. Phys. B 2005, 80, 915-921. [CrossRef]

102. Adeleye, A.S.; Keller, A.A.; Miller, R.J.; Lenihan, H.S. Persistence of commercial nanoscaled zero-valent iron (nZVI) and by-products. J. Nanopart. Res. 2013, 15, 1-18. [CrossRef]

103. Xia, T.; Kovochich, M.; Liong, M.; Madler, L.; Gilbert, B.; Shi, H.; Yeh, J.I.; Zink, J.I.; Nel, A.E. Comparison of the mechanism of toxicity of zinc oxide and cerium oxide nanoparticles based on dissolution and oxidative stress properties. ACS Nano 2008, 2, 2121-2134. [CrossRef] [PubMed]

104. Kadish, K.; Ruoff, R. Fullerenes: Chemistry, Physics, and Technology; John Wiley \& Sons: Hoboken, NJ, USA, 2000; Available online: https://books.google.de/books?hl=de\&lr=\&id=SQRugQM4p9QC\&oi=fnd\&pg= PR7\&dq=Kadish,+K.,+and+R.+Ruoff+.+2000.+Fullerenes:+Chemistry, + physics, + and +technology\&ots= OwZCpaA5h_\&sig=2Zy7vWWZ1iZbpTCIq4902e6uelg\#v=onepage\&q=solubility\&f=false (accessed on 30 September 2016).

105. Geckeler, K.E.; Premkumar, T. Carbon nanotubes: Are they dispersed or dissolved in liquids? Nanoscale Res. Lett. 2011, 6, X1-X3. [CrossRef] [PubMed] 
106. Klaine, S.J.; Alvarez, P.J.; Batley, G.E.; Fernandes, T.F.; Handy, R.D.; Lyon, D.Y.; Mahendra, S.; McLaughlin, M.J.; Lead, J.R. Nanomaterials in the environment: Behavior, fate, bioavailability, and effects. Environ. Toxicol. Chem. 2008, 27, 1825-1851. [CrossRef] [PubMed]

107. Seinfeld, J.H.; Pandis, S.N. Atmospheric Chemistry and Physics: From Air Pollution to Climate Change; John Wiley \& Sons: Hoboken, NJ, USA, 2012.

108. Hussein, T.; Hruška, A.; Dohányosová, P.; Džumbová, L.; Hemerka, J.; Kulmala, M.; Smolík, J. Deposition rates on smooth surfaces and coagulation of aerosol particles inside a test chamber. Atmos. Environ. 2009, 43, 905-914. [CrossRef]

109. Zhao, Y.; Wang, F.; Zhao, J. Size-Resolved Ultrafine Particle Deposition and Brownian Coagulation from Gasoline Vehicle Exhaust in an Environmental Test Chamber. Environ. Sci. Technol. 2015, 49, 12153-12160. [CrossRef] [PubMed]

110. Lowry, G.V.; Hotze, E.M.; Bernhardt, E.S.; Dionysiou, D.D.; Pedersen, J.A.; Wiesner, M.R.; Xing, B. Environmental Occurrences, Behavior, Fate, and Ecological Effects of Nanomaterials: An Introduction to the Special Series. J. Environ. Qual. 2010, 39, 1867-1874. [CrossRef] [PubMed]

111. Lin, D.; Tian, X.; Wu, F.; Xing, B. Fate and transport of engineered nanomaterials in the environment. J. Environ. Qual. 2010, 39, 1896-1908. [CrossRef] [PubMed]

112. Zuberi, B.; Johnson, K.S.; Aleks, G.K.; Molina, L.T.; Molina, M.J.; Laskin, A. Hydrophilic properties of aged soot. Geophys. Res. Lett. 2005, 32, L01807. [CrossRef]

113. Majestic, B.J.; Erdakos, G.B.; Lewandowsky, M.; Oliver, K.D.; Willis, R.D.; Kleindienst, T.E.; Bhave, P.V. A Review of Selected Engineered Nanoparticles in the Atmosphere: Sources, Transformations, and Techniques for Sampling and Analysis. Int. J. Occup. Environ. Health 2010, 16, 488-507. [CrossRef] [PubMed]

114. Levard, C.; Hotze, E.M.; Lowry, G.V.; Brown, G.E., Jr. Environmental transformations of silver nanoparticles: Impact on stability and toxicity. Environ. Sci. Technol. 2012, 46, 6900-6914. [CrossRef] [PubMed]

115. Jimenez, J.L.; Canagaratna, M.R.; Donahue, N.M.; Prevot, A.S.H.; Zhang, Q.; Kroll, J.H.; Aiken, A.C. Evolution of organic aerosols in the atmosphere. Science 2009, 326, 1525-1529. [CrossRef] [PubMed]

116. Tiwari, A.J.; Morris, J.R.; Vejerano, E.P.; Hochella, M.F., Jr.; Marr, L.C. Oxidation of C60 Aerosols by Atmospherically Relevant Levels of O3. Environ. Sci. Technol. 2014, 48, 2706-2714. [CrossRef] [PubMed]

117. Fortner, J.D.; Kim, D.I.; Boyd, A.M.; Falkner, J.C.; Moran, S.; Colvin, V.L.; Hughes, J.B.; Kim, J.H. Reaction of water-stable C60 aggregates with ozone. Environ. Sci. Technol. 2007, 41,7497-7502. [CrossRef] [PubMed]

118. Collins, P.G.; Bradley, K.; Ishigami, M.; Zettl, A. Extreme Oxygen Sensitivity of Electronic Properties of Carbon Nanotubes. Science 2000, 287, 1801-1804. [CrossRef] [PubMed]

119. Giannozzi, P. Oxygen adsorption on graphite and nanotubes. J. Chem. Phys. 2003, 118, 1003-1006. [CrossRef]

120. Goldoni, A.; Larciprete, R.; Petaccia, L.; Lizzit, S. Single-Wall Carbon Nanotube Interaction with Gases: Sample Contaminants and Environmental Monitoring. J. Am. Chem. Soc. 2003, 125, 11329-11333. [CrossRef] [PubMed]

121. Carp, O. Photoinduced reactivity of titanium dioxide. Prog. Solid Stat. Chem. 2004, 32, 33-177. [CrossRef]

122. Hou, W.C.; Jafvert, C.T. Photochemical transformation of aqueous C60 clusters in sunlight. Environ. Sci. Technol. 2008, 43, 362-367. [CrossRef]

123. Nissenson, P.; Knox, C.J.; Finlayson-Pitts, B.J.; Phillips, L.F.; Dabdub, D. Enhanced photolysis in aerosols: Evidence for important surface effects. Phys. Chem. Chem. Phys. 2006, 8, 4700-4710. [CrossRef] [PubMed]

124. Cheng, Y.; Yin, L.; Lin, S.; Wiesner, M.; Bernhardt, E.; Liu, J. Toxicity reduction of polymer-stabilized silver nanoparticles by sunlight. J. Phys. Chem. C Nanomater. Interfaces 2011, 115, 4425-4432. [CrossRef]

125. Wiesner, M.; Lowry, G.; Alvarez, P.; Dionysiou, D.; Bisawas, P. Assessing the role of manufactured nanomaterials. Environ. Sci. Technol. 2006, 40, 4336-4345. [CrossRef] [PubMed]

126. Egerton, T.A.; Mattinson, J.A. Comparison of photooxidation and photoreduction reactions on $\mathrm{TiO}_{2}$ nanoparticles. J. Photochem. Photobiol. A Chem. 2007, 186, 115-120. [CrossRef]

127. Chen, L.X.; Rajh, T.; Wang, Z.; Thurnauer, M.C. XAFS studies of surface structures of $\mathrm{TiO}_{2}$ nanoparticles and photocatalytic reduction of metal ions. J. Phys. Chem. B 1997, 101, 10688-10697. [CrossRef]

128. Linsebigler, A.L.; Lu, G.; Yates, J.T., Jr. Photocatalysis on $\mathrm{TiO}_{2}$ surfaces: Principles, mechanisms, and selected results. Chem. Rev. 1995, 95, 735-758. [CrossRef]

129. Ndour, M.; Conchon, P.; D'Anna, B.; Ka, O.; George, C. Photochemistry of mineral dust surface as a potential atmospheric renoxification process. Geophys. Res. Lett. 2009, 36. [CrossRef] 
130. Chen, H.; Nanayakkara, C.E.; Grassian, V.H. Titanium dioxide photocatalysis in atmospheric chemistry. Chem. Rev. 2012, 112, 5919-5948. [CrossRef] [PubMed]

131. Henderson, M.A. A surface science perspective on photocatalysis. Surf. Sci. Rep. 2011, 66, 185-297. [CrossRef]

132. Tatsuma, T.; Tachibana, S.I.; Miwa, T.; Tryk, D.A.; Fujishima, A. Remote bleaching of methylene blue by UV-irradiated TiO2 in the gas phase. J. Phys. Chem. B 1999, 103, 8033-8035. [CrossRef]

133. Daniels, S.L. On the qualities of the air as affected by radiant energies (photocatalytic ionization processes for remediation of indoor environments). J. Environ. Eng. Sci. 2007, 6, 329-342. [CrossRef]

134. Nanayakkara, C.E.; Larish, W.A.; Grassian, V.H. Titanium Dioxide Nanoparticle Surface Reactivity with Atmospheric Gases, $\mathrm{CO}_{2}, \mathrm{SO}_{2}$, and $\mathrm{NO}_{2}$ : Roles of Surface Hydroxyl Groups and Adsorbed Water in the Formation and Stability of Adsorbed Products. J. Phys. Chem. C 2014, 118, 23011-23021. [CrossRef]

135. Rubasinghege, G.; Elzey, S.; Baltrusaitis, J.; Jayaweera, P.M.; Grassian, V.H. Reactions on atmospheric dust particles: Surface photochemistry and size-dependent nanoscale redox chemistry. J. Phys. Chem. Lett. 2010, 1, 1729-1737. [CrossRef]

136. Bedjanian, Y.; El Zein, A. Interaction of $\mathrm{NO}_{2}$ with $\mathrm{TiO}_{2}$ Surface under UV Irradiation: Products Study. J. Phys. Chem. A 2012, 116, 1758-1764. [CrossRef] [PubMed]

137. Kebede, M.A.; Varner, M.E.; Scharko, N.K.; Gerber, R.B.; Raff, J.D. Photooxidation of $\mathrm{Ammonia}$ on $\mathrm{TiO}_{2}$ as a Source of $\mathrm{NO}$ and $\mathrm{NO}_{2}$ under Atmospheric Conditions. J. Am. Chem. Soc. 2013, 135, 8606-8615. [CrossRef] [PubMed]

138. Monge, M.E.; George, C.; D’Anna, B.; Doussin, J.F.; Jammoul, A.; Wang, J.; Mellouki, A. Ozone formation from illuminated titanium dioxide surfaces. J. Am. Chem. Soc. 2010, 132, 8234-8235. [CrossRef] [PubMed]

139. Chen, H.; Stanier, C.O.; Young, M.A.; Grassian, V.H. A kinetic study of ozone decomposition on illuminated oxide surfaces. J. Phys. Chem. A 2011, 115, 11979-11987. [CrossRef] [PubMed]

140. Pekney, N.J.; Davidson, C.I.; Bein, K.J.; Wexler, A.S.; Johnston, M.V. Identification of sources of atmospheric PM at the Pittsburgh Supersite, Part I: Single particle analysis and filter-based positive matrix factorization. Atmos. Environ. 2006, 40, 411-423. [CrossRef]

141. Weir, A.; Westerhoff, P.; Fabricius, L.; Hristovski, K.; Von Goetz, N. Titanium dioxide nanoparticles in food and personal care products. Environ. Sci. Technol. 2012, 46, 2242-2250. [CrossRef] [PubMed]

142. Li, Y.; Niu, J.; Zhang, W.; Zhang, L.; Shang, E. Influence of aqueous media on the ROS-mediated toxicity of $\mathrm{ZnO}$ nanoparticles toward green fluorescent protein-expressing Escherichia coli under UV-365 irradiation. Langmuir 2014, 30, 2852-2862. [CrossRef] [PubMed]

143. Nakajima, N.; Nishi, C.; Li, F.M.; Ikada, Y. Photo-induced cytotoxicity of water-soluble fullerene. Fuller Sci. Technol. 1996, 4, 1-19. [CrossRef]

144. Sakai, A.; Yamakoshi, Y.; Miyata, N. Visible light irradiation of [60] fullerene causes killing and initiation of transformation in BALB/3T3 cells. Fuller Sci. Technol. 1999, 7, 743-756. [CrossRef]

145. Misawa, M.; Takahashi, J. Generation of reactive oxygen species induced by gold nanoparticles under X-ray and UV irradiations. Nanomedicine 2011, 7, 604-614. [CrossRef] [PubMed]

146. Heckert, E.G.; Karakoti, A.S.; Seal, S.; Self, W.T. The role of cerium redox state in the SOD mimetic activity of nanoceria. Biomaterials 2008, 29, 2705-2709. [CrossRef] [PubMed]

147. Patakfalvi, R.; Diaz, D.; Velasco-Arias, D.; Rodriguez-Gattorno, G.; Santiago-Jacinto, P. Synthesis and direct interactions of silver colloidal nanoparticles with pollutant gases. Colloid Polym. Sci. 2008, 286, 67-77. [CrossRef]

148. Kerminen, V.-M.; Paramonov, M.; Anttila, T.; Riipinen, I.; Fountoukis, C.; Korhonen, H.; Asmi, E.; Laakso, L.; Lihavainen, H.; Swietlicki, E.; et al. Cloud condensation nuclei production associated with atmospheric nucleation: A synthesis based on existing literature and new results. Atmos. Chem. Phys. 2012, 12, 12037-12059. [CrossRef]

149. Tsai, Y.I. Atmospheric visibility trends in an urban area in Taiwan 1961-2003. Atmos. Environ. 2005, 39, 5555-5567. [CrossRef]

150. Malm, W.C.; Day, D.E. Estimates of aerosol species scattering characteristics as a function of relative humidity. Atmos. Environ. 2001, 35, 2845-2860. [CrossRef]

151. Tang, I.N.; Wong, W.T.; Munkelwitz, H.R. The relative importance of atmospheric sulfates and nitrates in visibility reduction. Atmos. Environ. 1981, 15, 2463-2471.

152. Waggoner, A.P.; Weiss, R.E.; Ahlquist, N.C.; Covert, D.S.; Will, S.; Charlson, R.J. Optical characteristics of atmospheric aerosols. Atmos. Environ. 1981, 15, 1891-1909. [CrossRef] 
153. ARIA Database, Accident $\mathrm{N}^{\circ} 43049$, Rejet de Noir de Carbone par une Usine de Pneumatiques. Available online: http:/ / www.aria.developpement-durable.gouv.fr (accessed on 2 May 2017).

154. Le, H.-D.; Lacome, J.-M.; Vignes, A.; Debray, B.; Truchot, B.; Fede, P.; Climent, E. A few fundamental aspects related to the modeling of an accidental massive jet release of nanoparticles. Chem. Eng. Trans. 2016, 48, $25-30$.

155. Le, H.-D.; Lacome, J.-M.; Vignes, A.; Debray, B.; Truchot, B.; Fede, P.; Climent, E. Modelling of test case particle-laden jet with NEPTUNE/CFD. In Proceedings of the 14th Workshop on Two-Phase Flow Predictions, Halle, Germany, 7-10 September 2015.

156. Ketzel, M.; Berkowicz, R. Modelling the fate of ultrafine particles from exhaust pipe to rural background: An analysis of time scales for dilution, coagulation and deposition. Atmos. Environ. 2004, 38, 2639-2652. [CrossRef]

157. Karl, M.; Kukkonen, J.; Keuken, M.P.; Lützenkirchen, S.; Pirjola, L.; Hussein, T. Modeling and measurements of urban aerosol processes on the neighborbood scale in Rotterdam, Oslo and Helsinki. Atmos. Chem. Phys. 2016, 16, 4817-4835. [CrossRef]

158. Nikolova, I.; Janssen, S.; Vos, P.; Berghmans, P. Modelling the Mixing of Size Resolved Traffic Induced and Background Ultrafine Particles from an Urban Street Canyon to Adjacent Backyards. Aerosol Air Qual. Res. 2014, 14, 145-155. [CrossRef]

159. Choi, W.; Paulson, S.E. Closing the UFP number concentration budget at road-to-ambient scale: Implications for particle dynamics. Aerosol Sci. Technol. 2016, 50, 448-461. [CrossRef]

160. Keuken, M.P.; Moerman, M.; Zandveld, P.; Henzing, J.S. Total and size-resolved particle number and black carbon concentrations near an industrial area. Atmos. Environ. 2015, 122, 196-205. [CrossRef]

161. Keuken, M.P.; Moerman, M.; Zandveld, P.; Henzing, J.S.; Hoek, G. Total and size-resolved particle number and black carbon concentrations in urban areas near Schiphol Airport (the Netherland). Atmos. Environ. 2015, 104, 132-142. [CrossRef]

162. Petroff, A.; Zhang, L. Development and validation of a size-resolved particle dry deposition scheme for application in aerosol transport models. Geosci. Model. Dev. 2010, 3, 753-769. [CrossRef]

163. Zhang, L.; Gong, S.; Padro, J.; Barrie, L. A size-segregated particle dry deposition scheme for an atmospheric aerosol module. Atmos. Environ. 2001, 35, 549-560. [CrossRef]

164. Zhang, J.; Shao, Y. A new parameterization of particle dry deposition over rough surfaces. Atmos. Chem. Phys. 2014, 14, 12429-12440. [CrossRef]

165. Manders-Groot, A.M.M.; Segers, A.J.; Jonkers, S. LOTOS-EUROS v2.0 Reference Guide; TNO Report TNO2016 R10898; TNO: Utrecht, The Netherlands, 2016.

166. Andronache, C.; Grönholm, T.; Laakso, L.; Phillips, V.; Venäläinen, A. Scavenging of ultrafine particles by rainfall at a boreal site: Observations and model estimations. Atmos Chem Phys 2006, 6, 4739-4754. [CrossRef]

167. Laakso, L.; Grönholm, T.; Rannik, Ü.; Kosmale, M.; Fiedler, V.; Vehkamäki, H.; Kulmala, M. Ultrafine particle scavenging coefficients calculated from 6 years field measurements. Atmos. Environ. 2003, 37, 3605-3613. [CrossRef]

168. Wang, X.; Zhang, L.; Moran, M.D. Uncertainty assessment of current size-resolved parameterizations for below-cloud particle scavenging by rain. Atmos. Chem. Phys. 2010, 10, 5685-5705. [CrossRef]

169. Gottschalk, F.; Sonderer, T.; Scholz, R.W.; Nowack, B. Modeled environmental concentrations of engineered nanomaterials $\left(\mathrm{TiO}_{2}, \mathrm{ZnO}, \mathrm{Ag}, \mathrm{CNT}\right.$, fullerenes) for different regions. Environ. Sci. Technol. 2009, 43, 9216-9222. [CrossRef] [PubMed]

170. Meesters, J.A.J.; Koelmands, A.A.; Quik, J.T.K.; Hendriks, A.J.; Van de Meent, D. Multimedia modeling of engineered nanoparticles with SimpleBox4nano: Model definition and evaluation. Environ. Sci. Technol. 2014, 48, 5726-5736. [CrossRef] [PubMed]

171. Gottschalk, F.; Sun, T.Y.; Nowack, B. Environmental concentrations of engineered nanomaterials: Review of modeling and analytical studies. Environ. Pollut. 2013, 181, 287-300. [CrossRef] [PubMed]

172. Karl, M.; Gross, A.; Pirjola, L.; Leck, C. A new flexible multicomponentmodel for the study of aerosol dynamics in the marine boundary layer. Tellus B 2011, 63, 1001-1025. [CrossRef]

173. Korhonen, H.; Lehtinen, K.E.J.; Kulmala, M. Multicomponent aerosol dynamics model UHMA: Model development and validation. Atmos. Chem. Phys. 2004, 4, 757-771. [CrossRef]

174. Vignati, E.; Wilson, J.; Stier, P. M7: An efficient size-resolved aerosol microphysics module for large-scale aerosol transport models. J. Geophys. Res. Atmos. 2004, 109. [CrossRef] 
175. Kokkola, H.; Korhonen, H.; Lehtinen, K.E.J.; Makkonen, R.; Asmi, A.; Järvenoja, S.; Anttila, T.; Partanen, A.-I.; Kulmala, M.; Järvinen, H.; et al. SALSA-A Sectional Aerosol module for Large Scale Applications. Atmos. Chem. Phys. 2008, 8, 2469-2483. [CrossRef]

176. Fountoukis, C.; Riipinen, I.; Denier Van Der Gon, H.A.C.; Charalampidis, P.E.; Pilinis, C.; Wiedensohler, A.; Dowd, C.O.; Putaud, J.P.; Moerman, M.; Pandis, S.N. Simulating ultrafine particle formation in Europe using a regional CTM: Contribution of primary emissions versus secondary formation to aerosol number concentrations. Atmos. Chem. Phys. 2012, 12, 8663-8677. [CrossRef]

177. Kukkonen, J.; Karl, M.; Keuken, M.P.; Denier van der Gon, H.A.C.; Denby, B.R.; Singh, V.; Douros, J.; Manders, A.; Samaras, Z.; Moussiopoulos, N.; et al. Modelling the dispersion of particle numbers in five European cities. Geosci. Model. Dev. 2016, 9, 451-478. [CrossRef]

178. Riipinen, I.; Pierce, J.R.; Yli-Juuti, T.; Nieminen, T.; Häkkinen, S.; Ehn, M.; Junninen, H.; Lehtipalo, K.; Petäjä, T.; Slowik, J.; et al. Organic condensation: A vital link connecting aerosol formation to cloud condensation nuclei (CCN) concentrations. Atmos. Chem. Phys. 2011, 11, 3865-3878. [CrossRef]

179. Pierce, J.R.; Riipinen, I.; Kulmala, M.; Ehn, M.; Petäjä, T.; Junninen, H.; Worsnop, D.R.; Donahue, N.M. Quantification of the volatility of secondary organic compounds in ultrafine particles during nucleation events. Atmos. Chem. Phys. 2011, 11, 9019-9036. [CrossRef]

180. Kranenburg, R.; Segers, A.J.; Hendriks, C.; Schaap, M. Source apportionment using LOTOS-EUROS: Module description and evaluation. Geosci. Model. Dev. 2013, 6, 721-733. [CrossRef]

(C) 2017 by the authors. Licensee MDPI, Basel, Switzerland. This article is an open access article distributed under the terms and conditions of the Creative Commons Attribution (CC BY) license (http:/ / creativecommons.org/licenses/by/4.0/). 